\title{
SAMIAN DEPOSIT (CACHE) FROM PAPKESZI (VESZPRÉM COUNTY, HUNGARY)
}

\author{
DÉNES GABLER* - ZSOLT MRÁV** \\ * Hungarian Academy of Sciences \\ Research Centre for the Humanities, Institute of Archaeology \\ 4 Tóth Kálmán utca, H-1097 Budapest Hungary \\ gabler.denes@btk.mta.hu \\ **Hungarian National Museum \\ 14-16 Múzeum krt, H-1088 Budapest, Hungary \\ mrav.zsolt@hnm.hu
}

\begin{abstract}
A collector handed over to the Hungarian National Museum 15 items of samian ware which he had discovered on the outskirts of Papkeszi. All of the vessels were plain ware: Drag. 33 cups or Drag.18/31 platters. 12 pieces bear stamps, with exception one they were all made by the workshops of Lezoux in the Antonine period. Their accordance as a set is evidenced by the graffiti naming Verus on 8 pieces.

The cache of Papkeszi and its closest paralell in space and time the one of Gorsium indicate that they were both purposely hidden deposits. Cache from the same era are also known from Noricum and Pannonia. Deposits from Gorsium and Aquincum can be related to the Marcomannic-Sarmatian attacks of AD 178-179 which among others resulted in the destruction of the earth-timber fort of Celamantia.

Based on samian and brooches the Roman settlement of Papkeszi was inhabited from the Flavian Age. Although its inhabitants might have hidden a cache of terra sigillata as a significant treasure, the Marcomannic-Sarmatian wars (AD 166-180) did not cause any considerable interruption in the occupation of the settlement.
\end{abstract}

Keywords: samian cache, stamps on Central Gaulish terra sigillata, Drag.33 cups, Drag 18/31 plates, Marcomannic-Sarmatian wars, graffiti

\section{INTRODUCTION}

In February 2015 István Horváth, a collector handed over 15 items of terra sigillata to the Hungarian National Museum which he had discovered on the outskirts of Papkeszi (Veszprém county), at the archaeological site registered as the Western entrance of the valley of Tekeres (Tekeresvölgy, MRT 2, 39/8) (Fig. 1), along with further Roman Age finds from the same site.

The terra sigillata vessels are parts of a single set. This is evidenced by the compatibility of the vessels, by their production and usage dated to the Antonine period, and also by the identical propreitary mark (name of the owner) scratched onto several of the pieces. The condition of the vessels also indicates a cache find: as reported by the collector, the fragments belonging to the set were collected at multiple occasions, from a specific zone, on the surface. Altogether, these conditions demonstrate that the probable not very carefully (only in a moderate depth) hidden cache was brought to light by plough, while during agricultural activity the direct archaeological context of the cache (e.g., the pit the depot was hidden in) was probably destroyed. 


\section{THE SITE OF THE CACHE}

The site of the hidden terra sigillata cache is located to the east of Papkeszi (Veszprém county), the territory of a settlement inhabited in the Roman era. This settlement is situated in the region surrounded by the natural borders of Sárvíz (stream), the Sárrét (marshland), and lake Balaton (lacus Pelso). The settlemet itself is located $5 \mathrm{kms}$ east of the lake Balaton. The area was part of the province of Pannonia Inferior, more closely, on the territory of civitas Eraviscorum, and after the foundation of Hadrianic municipality of Aquincum on the western periphery of the town's territories, close to the provincial border. The regional centre of the area, Tác-Fövenypuszta (Gorsium?), a significant vicus of the municipal territory of Aquincum and also a central settlement of a pagus in the $2^{\text {nd }}-3^{\text {rd }}$ centuries AD is located at the crossing point of the Sárvíz stream, $25 \mathrm{kms}$ to the south-west in a beeline.

Features of the Roman Age settlement at Papkeszi can be observed on the southern bank of Séd stream in an east-west direction, extending over 500 meters in length. Although on the territory multiple archaeological sites are registered (MRT 2, 39/8, 11, 12), most probably they indicate a single, extensive, but less densely covered settlement. Due to the lack of excavations it is unknown whether the settlement had a rural, village-type character at all, or whether it operated as a villa rustica during at least one of its archaeological periods.

The Roman era finds unearthed earlier at the site known as Sáripuszta can obviously be connected to this settlement. ${ }^{1}$ The most significant of these finds are: a „marble” banded female head (lost), ${ }^{2}$ a small bronze Mars statue $^{3}$ and a medallion of a funerary altar with an image of a married couple. ${ }^{4}$ The site has not been excavated yet, but during earlier and recent (2017) site surveys tile fragments and stone scree were observed on the surface. This suggests the presence of stone buildings in the settlement. Among them on the aerial photographs taken in June $2017^{5}$ a building of complex structure can also be recognized. As of today it is unknown whether the green, red and white wall painting fragments of the Horváth Collection belong to this building or other.

In course of the site survey in 2017 we were able to identify the location of the settlement's cemetery 200-250 meters from the settlement itself to the south-west on the eastern slope of a hill. Aerial photos marked a row cemetery and at least one circular ditch grave at this spot. Apart from household pottery and terra sigillata fragments we also unearthed coins, brooches, among them a disc-shaped fibula and a so-called almond fibula in the cemetery.

Based on the Horváth Collection and the finds of the site surveys the preliminary reconstruction of the chronology and the population of the settlement are as follows ${ }^{6}$ :

A La-Tène D or $1^{\text {st }}$ century antecedent of the settlement cannot be justified for the moment therefore most probably it was not continuously inhabited from the late Iron Age onwards. Two South Gaulish terra sigillata fragments from the Domitianic-Trajanic period, a great number of stamped, ${ }^{7}$ and also a few thin-walled ceramics indicate that the settlement existed at the end of the $1^{\text {st }}$ - beginning of the $2^{\text {nd }}$ century at the latest. This is also supported by a few metal finds, for instance, a bronze button-and-loop fastener, the closest parallel of which is known from the massive destruction layer of Sarmizegetusa's legionary camp dated to $105 \mathrm{AD}{ }^{8}$ The native Eraviscan population of the settlement is indicated by brooches associated with native female attire (Norico-Pannonian winged fibulae, kräftig profilierte fibulae with a single knob, Roman type cicada brooches), a fragment of a Tata type silver torques' terminal and a few mountings of native type female belts. The high number of marbled, orange and striped, painted

${ }^{1}$ F. RómER: Magyar régészeti krónika [Hungarian archaeological chronicle]. ArchKözl 6 (1866) 172, 180; D. LACZKÓ-GY. RHÉ: Baláca. Veszprém 1912, 15; KUZSINSZKY 1920, 200-203.

${ }^{2}$ F. RómER: A Bakony. Természetrajzi és régészeti vázlat [The Mountain Bakony. A natural historical and archaeological sketch]. Győr 1860, 152; MRT 2, 174, 39/***.

${ }^{3}$ KuZSINSZKY 1920, 202-203, Fig. 234.

${ }^{4}$ CSIR U 8, 91 n. 131; S. PALÁGYI: Veszprém megye római kőfaragványainak gyüjteménye. Katalógus - Sammlung der römerzeitlichen Steindenkmäler im Komitat Veszprém. Katalog. Veszprém 2004, 40, fn. 18 - cf. KuZSINSZKY 1920, 201-202, Fig. 233.

${ }^{5}$ Aerial photographs were taken in course of the Seuso research program's aerial archeological explorations by Máté Szabó.
${ }^{6}$ The complex research of the settllement is in progress, we plan further site surveys and geophysical surveys, as well as an excavation at the site.

${ }^{7}$ The vessel fragments decorated with a stamped design belong to the so-called pannonische Glanztonware East-Pannonian type. Based on their parallels the majority of the vessels can be connected to the pottery of the settlement at Lágymányos (Budapest, 11st district), to south Aquincum, which was active at the end of the $1^{\text {st }}$-beginning of the $2^{\text {nd }}$ centuries: A. NAGY: Forging Samian ware in the Pannonian way: the case of stamped pottery. Acta RCRF 43 (2014) 119-127. The stamped ceramics of the Horváth Collection are being processed by Alexandra Nagy (BTM, Museum of Aquincum), whose help and work we would like to thank hereby as well.

${ }^{8}$ FisCHER 2012, 333, Abb. 486.3. 


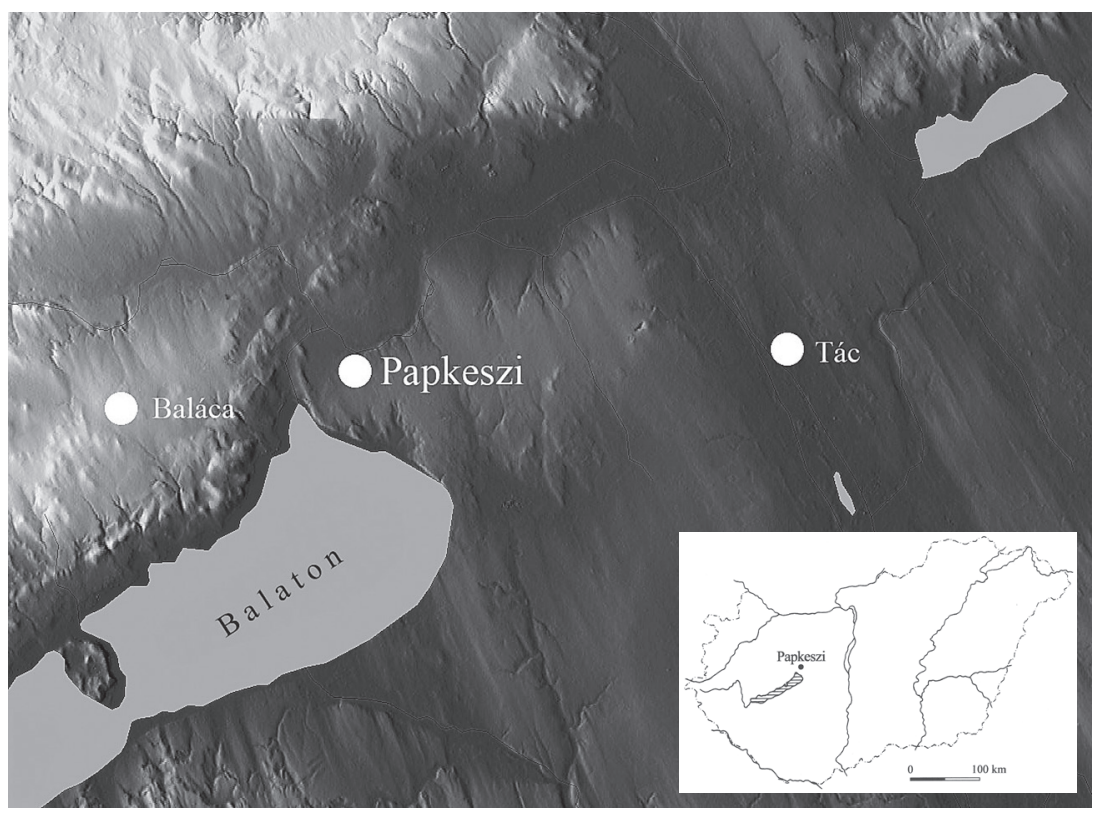

Fig. 1. Site of the samian cache (deposit)

ceramic fragments can also be associated with this period while the Antonine period is represented by Central Gaulish terra sigillata fragments. ${ }^{9}$

Based on the cache containing the terra sigillata set, similarly to the nearby vicus of Tác-Fövenypuszta, the settlement was most probably destroyed during the Germanic-Sarmatian wars in 178 AD. A depot find consisting of bronze vessels perhaps can also be connected to the same event, two jugs of which are preserved also in the Horváth Collection.

On the basis of the terra sigillata vessel fragments as well as other well datable imported ceramics (such as products from Raetia), the settlement was intensely inhabited again by the Severan period. Mountings ornamented with enamel inlaid, anchor and trumpet headed (one of them in silver) and most of the knee fibulae found at the site belong to this period. As it is evidenced apart from $3^{\text {rd }}$-century militaria (such as a strap terminal with ring in the middle and a hinged strap terminal, a niello inlaid late $3^{\text {rd }}$ century belt mounting and a looped belt mounting) also by an inscription, military families and settled veterans so typical in the $3^{\text {rd }}$ century were present in the settlement's population. Walled into a late Roman grave, a funerary tablet with an inscription was found at the nearby Tekeresi well (Rostás dülö) site, which on the basis of the funerary, was dated to AD 197: the table was erected by T. Fl(avius) T. fil. Qu(i)r(ina tribu) Ius(t)inus vet(eranus) leg(ionis) II Ad(iutricis) dom(o) Sirm(io) for himself and his wife. ${ }^{10}$

Apart from the inscriptions a fragment belonged to bronze compasses, a dark blue glass toy piece, a silver ring with a glass-paste gemma and a lead votive statuette are all indicative of the locally practiced intellectual and religious activities of the population. Iron agricultural tools indicate that besides military service the source of living of the settlement's population was agriculture. Equiculture is evidenced by the considerable number of bronze bridle and horse equipment mountings, among them a $2^{\text {nd }}$ century phallus amulet (fascinus).

As apart from a green-glazed mortarium ${ }^{11}$ it is evidenced by the numerous (26 pcs of) crossbow brooches, belt mountings (amphora and heart shaped strap terminals), rings with engraved bezels of the Horváth Collection and late Roman coins found during the site surveys that the settlement was probably still active and prosperous in the $4^{\text {th }}$ century. Other significant finds from this era are the so-called "Danubian Rider-god" or Dominus lead tablet fragment and a Tihany (Keller/Pröttel $5=$ Swift 5c) type, niello inlayed, plate crossbow brooch.

${ }^{9}$ A further Central Gaulish Drag. 37 form terra sigillata bowl fragment from Papkeszi is published by: CsIRKE-GABLERPALÁGYi 2006, 188, no. 35.1.
${ }^{10}$ RIU 1419; CSIR U VIII, 88, Nr. 123 (with further literature). For more information on the site of the funerary tablet, see: MRT 2, 39/10.

${ }^{11}$ MRT 2, 171, 39/8 
As it is indicated by its extension, as well as the abundance of archaeological finds and unique legacy of objects (caches, rare ceramic and metal finds) indicate that the Roman Age settlement to the east of Papkeszi was probably the most significant settlement of its closer region between the $2^{\text {nd }}-4^{\text {th }}$ centuries.

\section{SAMIAN CACHE FROM PAPKESZI}

All of the vessels are plain, Drag.33 form cups or Drag.18/31 form platters. The ratio of the two forms is $7: 8$, as the collection is supplemented by a larger version of the Drag. 31 form vessel, the so-called "Präsentierplatte". Unlike previously known sets, platters and cups are present in equal numbers in this case, although the original composition of the lot is unknown. 12 pieces bear stamps: with one exception, they were all made in the workshops of Lezoux in the Antonine period. Their accordance as a collection is evidenced by, among other things, the graffito naming "Verus" on 7 pieces. This sign of ownership was found on 4 vessels of form Drag.33 and 3 of form Drag. 18/31. Among the stamps, three names are present twice, such as Pauli m(anu), Reburri of(ficina) or Tittius fe(cit). Interestingly, all types of nomenclature were present in the collection, in the following ratio:

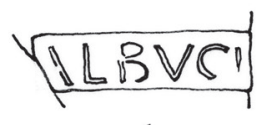

1

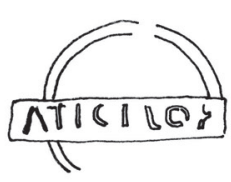

2

\section{BOR! O U}

3

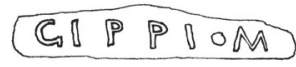

4

\section{TPADRIM}

5

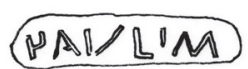

6

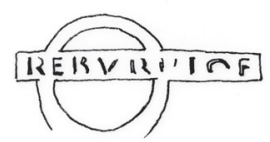

7

\section{RERQRRICF}

8

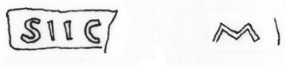

9

(TIT?

10

\section{LURTSTOF}

11

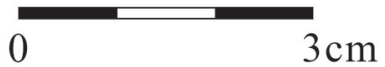

Fig. 2. Stamps on Samian ware of the deposit (cache) found at Papkeszi 


$\begin{array}{ll}\text { of }(\text { ficina }) & \text { in } 3 \text { cases, } \\ \mathrm{m}(\mathrm{anu}) & \text { “ } 4 \text { “ } \\ \mathrm{fe}(\mathrm{cit}) & \text { " } 3 \text { “ } \\ \text { genitive } & \text { " } 1 \text { “ } \\ \text { nominative? } & \text { " } 1 \text { “. Fruits }\end{array}$

The grafitti giving the name Verus in the genitive case is present on 4 Drag. 33 and on 4 Drag. 18/31 form vessels. Apart from that, the inscriptions DVM and LT have been scratched on two samian vessels.

\section{TERRA SIGILLATA OF THE DEPOSIT}

1. Drag. 33 form cup with a slightly concave wall, with a horizontal groove at its middle. Below the rim, in the inner wall, there is a moderate angle with a horizontal groove. The angle between the wall and the base is distinct. The floor is slightly raised towards the centre (Oswald-Pryce pl. LI.10) (Fig. 3.1). On the external surface of the base is a grafitti VERI. Rim diameter: $16.2 \mathrm{cms}, \mathrm{H}: 7.1 \mathrm{cms}$, Base diameter: $6 \mathrm{cms}$

Inv. HNM RR 2015.1.1 (Fig. 2.1)

The ALBVCI stamp on the Drag. 33 cup is clearly related to potter Albucius II working at Lezoux ${ }^{12}$ (stamp die 6b). We know of an earlier potter Albucius (Albucius I) from Les Martres-de-Veyre who is not the one who made our stamp. An Albucius II stamp (die 4a) was also discovered at Les Martres-de-Veyre in a kiln of the Antonine period, which means that the potter probably started his production there, but the majority of his products were made at Lezoux. The potter produced 18 forms, among them Drag.30 and Drag. 37 form bowls with relief decoration. Drag.18/31, Drag.18/31R, Drag.31 and Drag.31R form platters are also common elements of his repertoire. His activity is evident from before $160 \mathrm{AD}$, because he also produced Drag. 27 form cups as well. ${ }^{13} \mathrm{Cups}$, platters and relief-decorated bowls are represented in a relatively balanced manner in his production series. Only one stamp type occurs on the latter, which he probably used all the way through his activity. Although one of his stamped bowls shows significant similarities with the type of imagery used by Cinnamus, ${ }^{14}$ it is without doubt a product of Albucius II, as it is decorated with his ovolo. In any case, this means that there probably was some kind of connection between the two workshops: perhaps Albucius imitated the style of Cinnamus. Among the stamp types present on his plain vessels, 3a and $3 \mathrm{c}$ might be early types, as they are present on Drag. 27 form vessels - although 3a also appears on the later 79R type. Stamps presenting the abbreviation of the officina are relatively rare in his repertoire ${ }^{15}$; only $15 \%$ of his known stamps have it. Мапи type stamps also occur in his repertoire ${ }^{16}$ which might indicate that Albucius made the vessels himself. Stamps are relatively uniform, but the styles which are found associated with die 5a, 7e and $7 \mathrm{~b}$ are different: the poinçon might have been made by a different potters, but this assistant was undoubtedly working for Albucius II. Perhaps this potter specialized in name stamp production. There is no other name displayed in the field of his decorated ware $;{ }^{17}$ on rim stamps, the names Cadgatus, Cintusmus, Osbimanus and Priscus are present. Bowls with relief decoration were possibly made in his own workshop from such dies that were borrowed or copied from other potters. The name Cintusmus also occurs on products of other potters, on the rim stamp. His decorated bowls were found at Aquincum in the destruction layer related to the Marcomannic-Sarmatian wars, in the area of the tabernae; the destruction layer can be dated presumably to $178 .{ }^{18}$

The distribution area of his ware is significant: they reached Britannia, Upper Germania and the Danubian provinces. In the lower Rhine territories their occurrence is very limited: only the Drag. 27 type of his products is present in this area, and this may be connected to the observation that only very few examples of the early types got into Germania inferior (stamp variations of Albucius II 3a, 3c, 6b, 6c). His ware might have arrived in the Danubian provinces in the period before 170/178.

Based on the above discussion, the active period of the potter can be dated to the years between $145-180 .{ }^{19}$ His plain ware with stamps is common in Pannonia: his stamp appears on Drag.18/31 form platters from

\footnotetext{
${ }^{12}$ Bet-Delage 1991, No 36, 214.

${ }^{13}$ See Gabler-Márton 2009, 225.

${ }^{14}$ Rogers 1999, pl. 2,1.

${ }^{15}$ JuHÁsz 1935, Nr.11, 135, Taf. XLIV.11
}

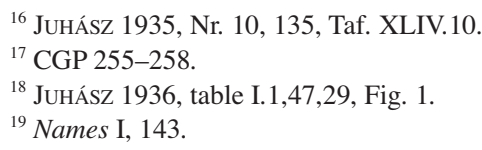



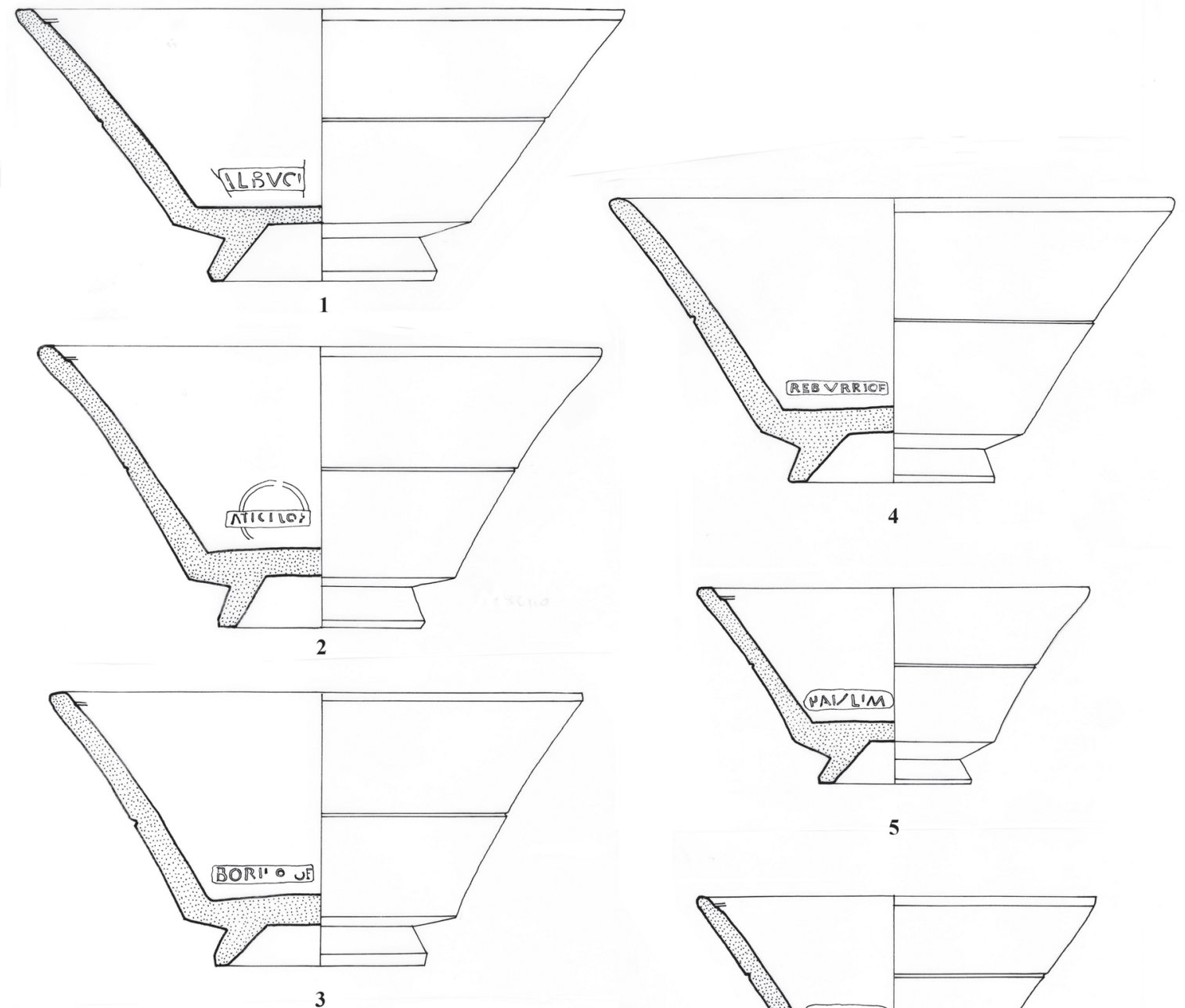

5
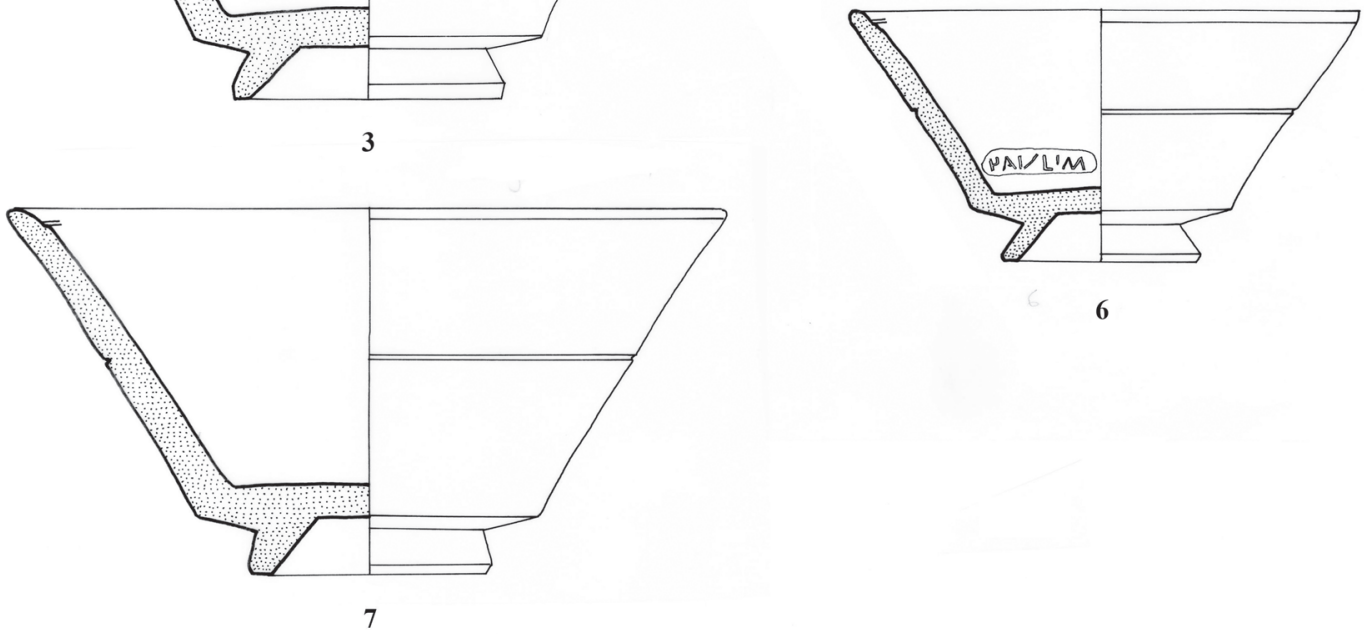

6

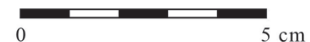

tow

Fig. 3. Cups Drag. 33 of the deposit found at Papkeszi 
Vindobona, ${ }^{20}$ Brigetio, ${ }^{21}$ Carnuntum, ${ }^{22}$ Gorsium, ${ }^{23}$ Tokod ${ }^{24}$ and Salla. ${ }^{25}$ Somewhat fewer stamps appear on Drag.33 cups, at Poetovio ${ }^{26}$, Sárvár ${ }^{27}$ and Vetus Salina. ${ }^{28}$ His stamped ware also occurs at Scarbantia, Savaria and Teskánd, but in these cases the vessel type where the signatura appears is unknown. ${ }^{29}$

2. Drag. 33 cup with a slightly concave wall, with a horizontal groove at the middle. There is a distinct angle between the side and the base. The floor is very slightly convex. Below the rim, on the inner side, there is a groove (Pudding Pan Rock form 13; Oswald-Pryce pl. LI.11; Faber 1994, Beil. 10,104; Düerkop-Eschbaumer 2007, Taf. 34). (Fig. 3.2)

Rim diameter: $14.5 \mathrm{cms}, \mathrm{H}: 7.3 \mathrm{cms}$, Footring diameter: $5.4 \mathrm{cms}$

On the bottom of the cup, ATICI.SO I stamp

Inv. HNM RR 2015.1.2 (Fig. 2.2).

The signatura can be related to a Central Gaulish potter in, who produced an orange and also a clay-colored fabric. Presumably he was a potter from Lezoux; at least, the distribution of his ware supports this idea. Usually Aticiso made Drag.33 cups, but his product range also included form Drag.27. Therefore, the production of the workshop can be dated before 160. B. Dickinson and B. Hartley date his activity to the period 140-180; the pieces from Corbridge can be dated to the Antonine period. The last letter of this stamp, representing die 1a, seems to be an I, but in some cases, they read it rather as an $\mathrm{F}^{30}$ So far the stamp has been recorded mainly from Britannia and Augusta Raurica. It was previously unknown from Pannonia.

3. Drag. 33 form cup with a slightly concave wall, with a horizontal groove at the middle. There is a sharp division between the side wall and the base. Below the rim, there is a grooved horizontal line. The base is convex towards the middle (Oswald-Pryce pl. LI.11; Pan Rock form 13).

On the side of the vessel, a scratched inscription

Rim diameter: $13.6 \mathrm{cms}, \mathrm{H}: 7.2 \mathrm{cms}$, Footring diameter: $5.4 \mathrm{cms}$

Inv. HNM RR 2015.1.3

On the Drag. 33 form cup there is a BORILLI OF stamp, ${ }^{31}$ which is a die $5 b$ of the stamps identified by B. Dickinson and B. Hartley (Fig. 2.3).

In Lezoux, below a kiln that can be related to Borillus I, Plicque found in 1887 pieces of coins minted in 176; the dating of his latest production is based on this observation. However, early in the stamp series, die $10 \mathrm{~d}$ appear on Drag. 27 and Drag.18/31R form platters in the Helsoven tumulus in a complex that can be dated to the period 135-155. In a pottery shop at Castleford which was destroyed in a fire in the 140s, two burnt bowls stamped from die 10a were unearthed that were most probably made in the first half of the 140s. Among the ware of Borillus, the latest plain form is a single example of form 79R, which can be dated no earlier than 170. This potter produced only a small quantity of vessels with relief decoration ${ }^{32}$; all of them bear the $10 \mathrm{~b}$ stamp version (Borilli m). His use of motifs and compositions of bowls with relief decoration are closely connected with the products of the (early) Cerialis II-Cinnamus II group and of Cinnamus's later production at Lezoux. The stamps of Borillus are more common in the military sites near the Antonine Wall in Scotland than along Hadrian's Wall. His production period ends in the third quarter of the $2^{\text {nd }}$ century and can be dated more precisely to the decades between $145-175 .{ }^{33}$ The wares of Borillus were found in greater quantities in Britannia, and so far, relatively few of them have been recorded from Gaul and Germania superior. ${ }^{34}$

${ }^{20}$ Donat 1999, 212

${ }^{21}$ JuHÁsz 1935, Nr. 9, 135, Taf. XLIV.

${ }^{22}$ Names I, 142.

${ }^{23}$ Gabler-Kocztur 1976, Nr. 6, 301, 333, Taf. V.18; BÁNKI 1987, Nr. 179, 227, Taf. XXXIX.

${ }^{24}$ GABLER 1964, 100.

${ }^{25}$ GABLER 1989, Nr. 86, 448.

${ }^{26}$ Mikl Curk 1969, Nr. 259, 35, Taf. XXII.

${ }^{27}$ Gabler 1997, 50, Nr. 62, 70, Taf. 7,5.
${ }^{28}$ BARKócZI-BóNIS 1954, Nr. 133, 173, Abb. 17,5, Taf.

XLIV.6.

${ }^{29}$ GABLER 1964, 100.

${ }^{30}$ Names I, 289.

${ }^{31}$ Names II, 100

32 JuHÁsZ 1935, 37; BeT-Delage 1991, 214.

${ }^{33}$ Names II, 105 . According to J. A. Stanfield and G. Simpson 140-160 (CGP 311), while according to G. Rogers 145-180 (ROGERS 1999, 72-74).

${ }^{34}$ Names II, 100-101. 

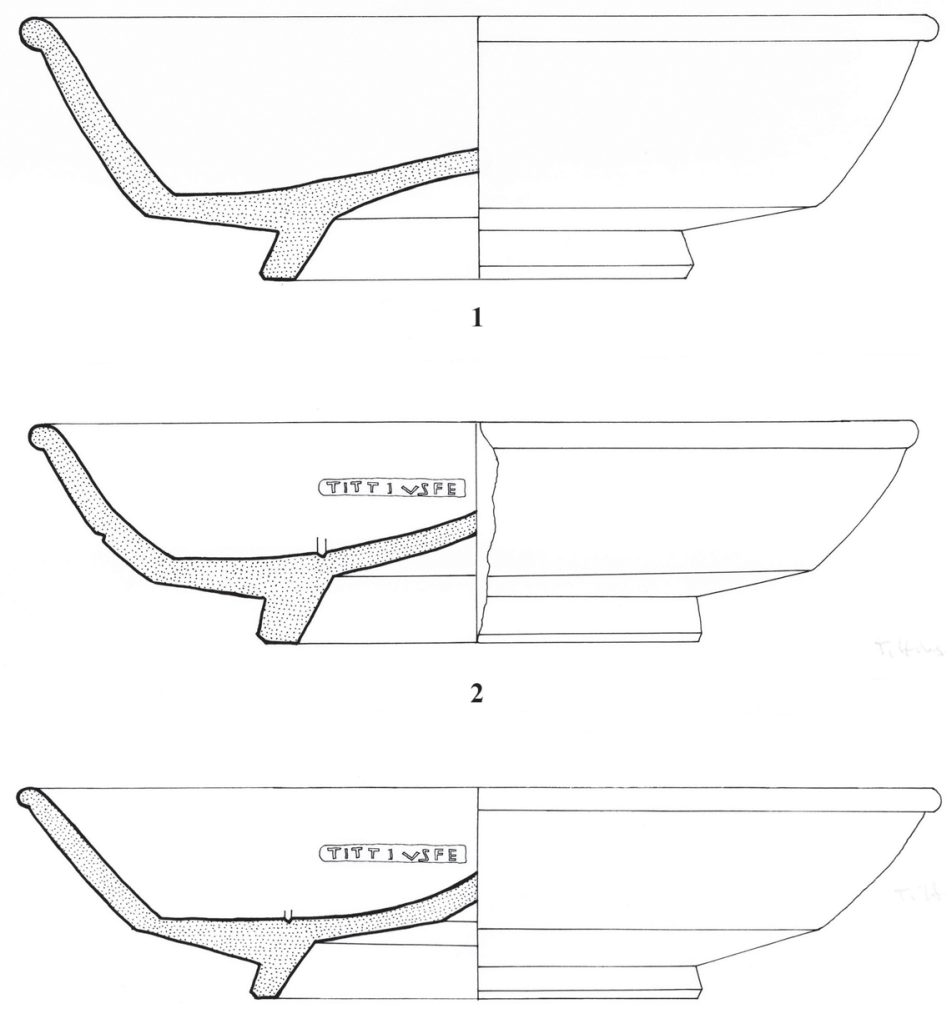

3

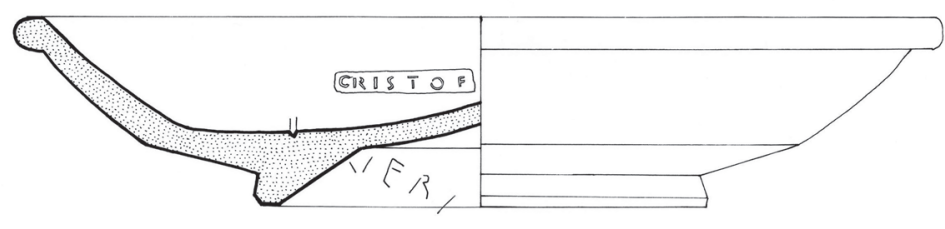

4

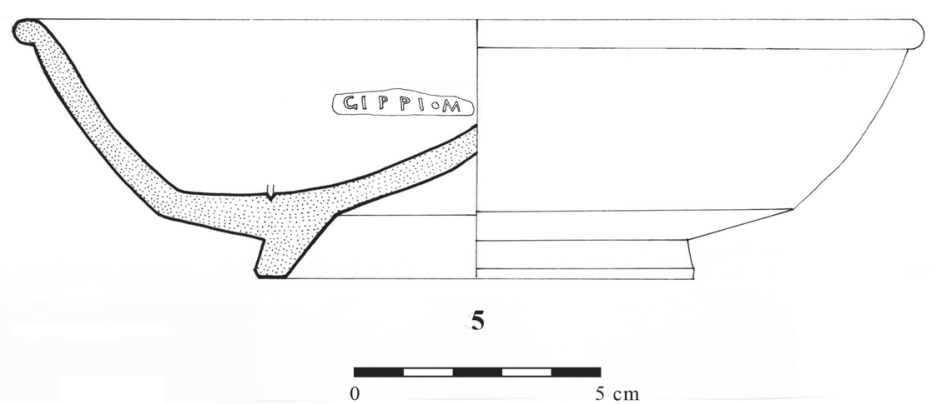

Etgor

Fig. 4. Platters Drag. $18 / 31$ of the deposit found at Papkeszi 
Iustus is also listed among the associated potters, whose stamps can be found on the vessels of Gippus. The stamp SERVIMAC appears on a bowl made in the same style and thus he can probably be identified with the potter who prepared the die. Gippus's production range, apart from Drag.18/31-31 type plates, probably included Drag. 27 and Drag. 33 cups and the Drag.38 flanged bowl.

Relief-decorated and plain ware bearing these stamps can be dated to the same period, and it is certain that they are connected to the same potter, one who may have employed other potters occasionally. Gippus's products were mostly distributed in the Danubian provinces, but numerous examples are recorded from Britannia as well. Although only a few stamps are known from Gaul, they are relatively frequent among finds from Augusta Raurica, Straubing ${ }^{45}$ and Kempten. ${ }^{46}$

B. Dickinson and B. Hartley dated the activity of Gippus to the period between 155 and 180 . The 2a type stamp appears on a Drag. 27 form cup at Londinium and thus Gippus might already have started production before 160. The secondarily burnt $\operatorname{depot}^{47}$ from both Aquincum and Gorsium give evidence that his products may have reached Pannonia before the period of the Marcomannic wars.

Only samian vessels of forms Drag.33 and Drag.18/31 were transported to our province from this officina. Gippus's Drag.33 form cup was discovered at Brigetio, Carnuntum and Poetovio, while his Drag.21 and Drag.18/31 form plates were found at Carnuntum, Aquincum, Baláca and Gorsium. ${ }^{48}$

In Pannonia, the following stamp types occur:

$\begin{array}{ll}\text { G.IPPI·M } & \text { at Baracs } \\ \text { GIPPI M } & \text { at Matrica and Gorsium } \\ \text { G PPI·M } & \text { at Mursa } \\ \text { GIPPI.M } & \text { at Carnuntum (multiple examples), Brigetio, Aquincum, Gorsium } \\ \text { GIPPI[. } & \text { at Poetovio and Gorsium } \\ \text { GIPP[ } & \text { at Gorsium } \\ \text { GIP[ } & \text { at Aquincum } \\ \text { ]PPI·M } & \text { at Aquincum and Gorsium } \\ \text { ]PI·M } & \text { at Baláca }\end{array}$

Products of his potter can be found also at Arrabona and Kömlőd; however, the type of stamp is unknown. ${ }^{49}$

6. Drag.33 form cup with a slightly concave wall, with a horizontal groove at the middle. Below the rim, the mild gradient of the wall displays a horizontal line. The foot ring is relatively slim. The angle between the side wall and the base is not very distinct; the floor is almost completely flat (Curle 16/18; Oswald-Pryce pl. LI.12; Faber 1994, Beil. 10,98; Düerkop-Eschbaumer 2007, Abb. 33 835.2). See Gabler-Kocztur 1976, Taf. 5,17-19 (Fig. 3.5). There is a graffito on the cup.

Rim diameter: $10.2 \mathrm{cms}$, H: $5.2 \mathrm{cms}$, Base diameter: $4 \mathrm{cms}$

Inv. HNM RR 2015.1.6

Stamp PAVLIM is on the bottom.

In the majority of Paullus's stamps, two Ls are visible. Most probably, potter Paullus V had his workshop at Lezoux ${ }^{50}$ even though only a few artifacts from that production centre are known for him. ${ }^{51}$ Besides form Drag.33, this potter produced Drag.31, Drag.31R, Walters 79 and 80 type vessels. Drag. 32 form does not yet appear in his repertoire, while the lack of Drag. 27 suggests that the production years of his workshop were after 160. This is also confirmed by the fact that his products emerge at sites in Britannia that are assumed to had been invaded around 160, after being abandoned in the reign of Hadrian. ${ }^{52}$ Some of his stamps can be dated to the last decades of the $2^{\text {nd }}$ century. The die $4 \mathrm{a}$, a type similar to our stamp, was also found in the earth-timber fort of Celamantia, which could not yet have been in use between 175 and 180. Consequently, his production can be dated to the period be-

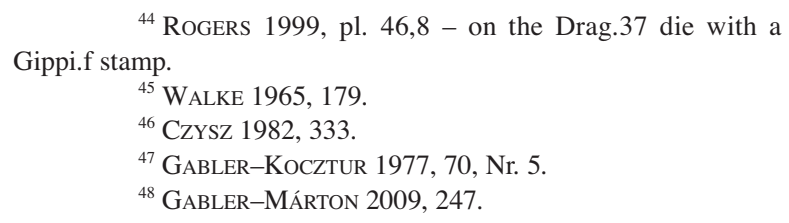

203.

\footnotetext{
${ }^{49}$ GABLER-MÁRTON 2009, 247.

${ }^{50}$ Bet 1988, 666; Tilhard 2004, 240; Dickinson 2001,

${ }^{51}$ Names 7, 114.

${ }^{52}$ Names $7,114$.
} 
tween 165 and 200. He did not produce decorated bowls; only moulds can be designated to him. He might have been in an association with potter Sedatus V.

One of the most important markets of Paullus V's ware was probably Britannia, where several examples are recorded. However, in Gaul and Germania superior, his stamps have been discovered at, and published from, only a few sites. They are also absent from Noricum, but from Raetia, there are 9 registered items. ${ }^{53}$ In Pannonia, the following Drag. 33 form cups can be connected to Paullus V's workshop: 2 from Celamantia, one from Brigetio, one from Aquincum, and presumably, one-one from Poetovio and Mursa. Stamps of this potter are less frequent on Drag. $18 / 31$ form plates, they are present at Gerulata, Brigetio and Aquincum. ${ }^{54}$ Stamps of the earlier Paullus IV, active between 135 and 165, are present on Drag.33 form cups (Brigetio, Carnuntum) and Drag.18/31 type plates (Brigetio, Salla). A more closely non-identifiable P]AVLIM stamp is present on a Drag.38 (?) form mortarium in Poetovio. The PAVLIM stamp present on an item from Vindobona cannot be classified within the system of known types. ${ }^{55}$

The following examples of potter Paullus V's stamp types are present in Pannonia:

PAVLI·M at Celamantia (Drag. 33 forms)

PAVLIM at Brigetio (both on Drag.33 and Drag.18/31 form), Aquincum (on Drag.33 and Drag.31 forms), Gerulata (Drag.18/31 form), Poetovio (on Drag. 33 form) and Mursa (on Drag. 33 form) $)^{56}$ Szekszárd-Palánk (on Drag.33)

7. Drag. 33 form cup with a slightly concave wall. On the middle of the wall, a horizontal groove. Below the rim, on the inner side of the vessel, a similiar horizontal line. The base is slightly raised towards the middle (Oswald-Pryce pl. LI.12; Düerkop-Eschbaumer 2007, Abb 34,11 (Fl 2) 35) (Fig. 3.6).

Inv. HNM RR 2015.1.8

There is a grafitto VERI on the vessel.

Rim diameter: $10.3 \mathrm{cms}, \mathrm{H}: 5.2 \mathrm{cms}$, Footring diameter: 4 cms (Fig. 2.6)

On the bottom of the cup, the stamp PAVLIM

8. Drag. 33 form cup with an almost straight wall, grooved at its middle. There is a distinct angle between the side wall and the base. The floor is almost completely flat (Oswald-Pryce pl. LI.11; Faber 1994, Beil. 10,103) (Fig. 3.4).

Rim diameter: $14.7 \mathrm{cms}, \mathrm{H}: 7.6 \mathrm{cms}$, Base diameter: $6.4 \mathrm{cms}$

Inv. HNM RR 2015.1.8

There is a grooved character and a stamp reading REBURRI.OF on the $\operatorname{cup}^{57}$ (Fig. 2.7).

Based on the frequent occurrence of his work, Reburrus II was probably a potter from Lezoux. ${ }^{58} 14$ main versions of his stamps are recorded: the present one can be classified as $4 \mathrm{~g}$. He produced early Antonine forms: Drag. 27 form cups and Drag.18/31R type dishes; less frequently, he produced variants that can be dated after 160, such as Walters 79 type dishes. This latter type is much less frequent. His form repertoire also included Drag.33, Walters 80, Drag.38, Drag.46, Lud Tg and Drag.15/31 form vessels. His production before 160 can be supported by the frequency of the Drag. 27 form. His stamp is present on secondarily burnt vessels (burnt in fires of the Antonine period) at Bainbridge and Gauting. The presence of his stamp on the model of Casurius II also furnishes evidence for the later date of his activity in the period between 140 and $170 .{ }^{59}$

The export area of his ware included Britannia, Gaul, and parts of Germania inferior. They are more frequent in Raetia, Noricum ${ }^{60}$ and Pannonia and they reached Moesia superior as well. ${ }^{61}$

In Pannonia, Reburrus's stamp can be found on Drag. 33 form cups at Tokod and Aquincum, while the first recorded occurrence of the Drag.18/31 type is the present item from Papkeszi.

\footnotetext{
${ }^{53}$ KuZMOVÁ 2016, 605.

${ }^{54}$ KuZMOVÁ 2016, 604.

${ }^{55}$ Fr. VON KENNER: Römische Funde in Wien aus den Jahren 1901 bis 1903. JZK N.f. 2/1-3 (1904) 164.

${ }^{56}$ GABLER-MÁrTON 2009, 266.
}

\footnotetext{
${ }^{57}$ Names 7, 327.

${ }^{58}$ Tilhard 2004, 246

${ }^{59}$ HARTLEY 2000, 196; DiCKINSON 2001, 204.

${ }^{60}$ Names $7,327$.

${ }^{61}$ BJELAJac 1990, 97.
} 
His stamp types from Pannonia are:

\begin{tabular}{|c|c|}
\hline Reburri·of & from Ráckeve and Tokod \\
\hline Reburri (hedera) of & from Aquincum \\
\hline $\begin{array}{l}\text { Rebu[r]ri (hedera) of } \\
\text { Reburrio }\end{array}$ & $\begin{array}{l}\text { from Arrabona } \\
\text { from Aquincum }\end{array}$ \\
\hline
\end{tabular}

9. 14 fragments of a Drag.18/31 form plate with the stamp REBURRI OF. The rim is beaded, its side wall is slightly curved. Between the base and the side wall the transition is mild, there is no strong? division. The omphalos is raised high (Faber 1994, Beil. 7,23). The clay is purple-red; its surface is deep red and matte.

Extracted diameter: $16 \mathrm{cms}$, Footring diameter: $9 \mathrm{cms}$ (Fig. 2.8)

Inv. HNM RR 2015.1.8

10. Drag. $18 / 31$ form plate bearing the stamp SIICV[DI]M (Fig. 5.2).

Inv. HNM RR 2015.1.10

The potter who produced the vessel was probably Secundus $\mathrm{V},{ }^{63}$ the signatura seems to be die $2 \mathrm{~b}$ (Fig. 2.9). The production centre of this potter was also Lezoux, ${ }^{64}$ where he was active between 145 and 175 . In the production might have involved more than one Secundus; their differentiation is almost impossible on the basis of the data provided by publication. J. A. Stanfield and G. Simpson refer to a Secundus among the potters who produced decorated samian also. On his bowls with relief decoration he used Cinnamus II's ovolo types or occasionally, Divixtus I's. As for Pannonia, the workshop(s) exported Drag. 27 form cups (Carnuntum), Drag.31 type plates (Salla) and Drag. 33 form cups (Mursa, Savaria, Brigetio). ${ }^{65}$

The following stamp variants are known from Pannonia:

Secundi $m \quad$ from Mursa and Savaria

Secundi $\mathrm{m}(\mathrm{)} \quad$ from Brigetio

Siicundi from Vindobona

Siicu[ from Salla

$\operatorname{Sec}[$ ] from Carnuntum

]ecundi $\mathrm{m} \quad$ from Brigetio

A Siicudim stamp, similar to the present one, occurs on a vessel from Carnuntum. ${ }^{66}$

11. The stamp TITTIUSFE is present on two Drag. 18/31 form plates.

The higher plate has a beaded rim, a slightly curved wall and a low foot ring. There is a distinct angle between the base and the side wall. The floor rises steeply in the middle; the omphalos is closer to the rim (OswaldPryce pl. XLVI.9; Lud Tq; Faber 1994, Beil. 7,31). There is a circular groove above the foot ring (Fig. 4.3).

On the plate, scratched letters: VERI and X.

Catinus bessalis.

Diameter: $18.6 \mathrm{cms}, \mathrm{H}: 4.4 \mathrm{cms}$, Footring diameter: $9 \mathrm{cms}$ (Fig. 2.10)

Inv. HNM RR 2015.1.11

The type mostly corresponds to Hartley-Dickinson's 2a, but the one from Papkeszi is slightly bigger. ${ }^{67}$ Based on the drawings, its stamps are difficult to connect to classified forms. It is also possible that more potters named Tittius were working at Lezoux. The Tittius on our stamp produced Drag.27, Drag.18/31, Drag.18/31R, Drag.31, Drag.33 and Drag.46 ? forms. Based on the relatively frequent Drag.27 type (Cirencester, Carlisle, Corbridge, South Shield, Verulamium, Augsburg) dating it to the Hadrian-early Antonine period seems supported. The potter also produced decorated Drag. 37 type bowls, which suggest that he had connections with Cinnamus II and Pugnus II. ${ }^{68}$ Cassia's stamp also occurs on one of his decorated bowls; thus Tittius probably made Cassia's 2004,254

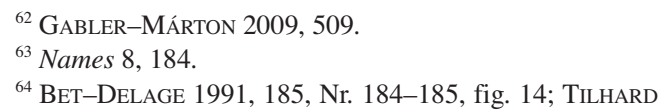

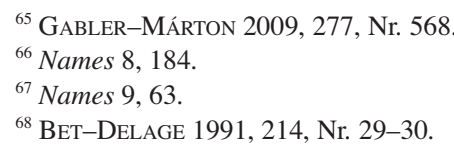



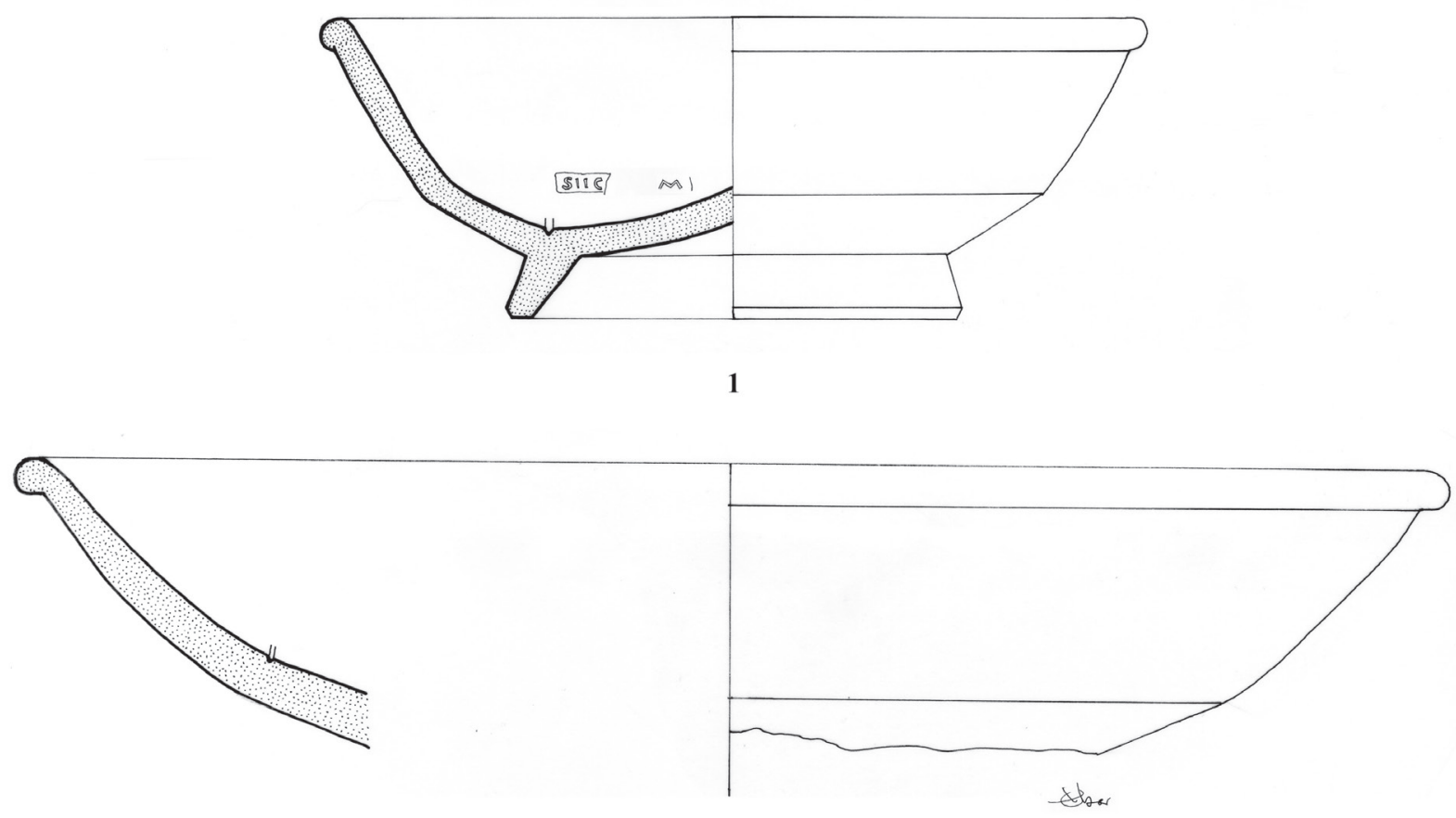

2

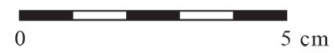

Fig. 5. Platters Drag. $18 / 31$ of the deposit found at Papkeszi

mould. ${ }^{69}$ His Drag. 37 form bowls are recorded also from the Danubian provinces, such as those from Ovilava ${ }^{70}$ or Vindobona. ${ }^{71}$

His production is dated by Dickinson and Hartley to the decades between 130 and $160,{ }^{72}$ while J. A. Stanfield and G. Simpson had previously suggested a dating between 140 and 180. Ware of this potter were mostly distributed on the markets of Britannia, but they are also to be found in Central and Eastern Gaul, Germania inferior and superior, Raetia, Noricum and Pannonia. To the last location, the workshop transported Drag. 33 and Drag. 18/31 samian types alike. On Drag. 33 form cups, Tittius's stamp is known from Brigetio and Aquincum; on Drag. 31 and Drag. 18/31 type plates, the stamp is known from Aquincum and Gorsium.

The following stamp types are recorded from Pannonia. ${ }^{73}$

Tittius fe from Aquincum, Albertfalva and Gorsium

Tittius from Carnuntum, Brigetio and Aquincum

Tittius [ from Gorsium

Titt[ from Aquincum

12. The larger fragment of a Drag. $18 / 31$ platter, with a TITTIUSF stamp similar to the one on the previous item. Catinus bessalis with a beaded rim and a slightly curved wall. Between the base and the side, a distinct edge.

${ }^{69}$ CGP 1990, 291.

${ }^{70}$ KaRNITSCH 1959 , Taf. 40,7.

${ }^{71}$ WeBER-HIDEN 1996, Taf. 54,3.

\footnotetext{
${ }^{72}$ Names 9, 63 similarly TILHARD 2004, 263.

${ }^{73}$ Gabler-MÁrton 2009, 283, Nr. 620.
} 
Above the thicker footring, a groove. The omphalos is highly drawn up (Gabler-Kocztur 1976, Abb. 4,3-7; Faber 1994, Beil. 7,28) (Fig. 4.2).

Inv. HNM RR 2015.1.12

Rim diameter: $18 \mathrm{cms}, \mathrm{H}: 4.4 \mathrm{cms}$, Footring diameter: $9 \mathrm{cms}$

13. Drag. 33 form cup with an almost straight wall, and a horizontal groove in the middle of the wall. A similar, but thinner line is visible below the rim on the inner wall. Between the side wall and the short base, a distinct angle. The base is slightly convex (Oswald-Pryce pl. LI.11). On this particular vessel, there is a scratched $\mathrm{X}$, representing a mark of ownership. Without a stamp.

Rim diameter: $14.5 \mathrm{cms}, \mathrm{H}: 7.6 \mathrm{cms}$, Footring diameter: $4.9 \mathrm{cms}$ (Fig. 3.7)

Inv. HNM RR 2015.1.13

14. Drag. $18 / 31=$ Lud-Tq/Sa form platter with a beaded rim and an almost straight wall. There is a sharp division between the base and the side wall. The base rises slightly towards the middle of the vessel; the omphalos is slightly raised. (Faber 1994, Beil. 7,33; Czysz 1982, Abb. 10,5). Coral red, glossy slip.

Diameter: $18.7 \mathrm{cms}, \mathrm{H}: 5.3 \mathrm{cms}$, Footring diameter: $8.6 \mathrm{cms}$ (Fig. 4.1)

Inv. HNM RR 2015.1.14

15. Fragment of a larger, Drag.31 form platter ("Präsentierplatte" and catinus pedalis 7), with a beaded rim, and a slightly curved, higher wall that continues into the base without a sharp division. (Faber 1994, Beil. 7,41; Czysz 1982, Abb. 11-13). Glossy, coral red slip.

Extracted diameter: $29.8 \mathrm{cms}$ (Fig. 5.3)

Inv. HNM RR 2015.1.15

\section{FORMS OF THE TERRA SIGILLATA CACHE AND PARALLELS OF THE ASSEMBLAGE}

All but one of the platters indicate Drag.18/31 forms. The item with the CRISTOF stamp can be considered as the earliest among them: this one is flatter and its walls are leaning. In the classis camp of Alteburg, Cologne, this type is present already in the $120 \mathrm{~s}$, in the destruction layer of the $6^{\text {th }}$ phase. ${ }^{74}$ An early example from Southern Gaul, from Regensburg-Kumpfmühl also indicates this type. Towards the end of the auxiliary fort there, the form becomes less frequent. ${ }^{75}$ Production of the vessel type with a high omphalos, a distinct edge and a TITTIUSFE stamp began in the middle of the $2^{\text {nd }}$ century and continued until the 170 s at most. ${ }^{76}$ Platter No. 12 is a frequent type in the III/IV phase of Newstead. Its parallels in the cache finds at Gorsium can be dated to around 178. In the fort at Regensburg-Kumpfmühl, similar platters are present in the material of the $2^{\text {nd }}$ phase. The production of this type began before the middle of the $2^{\text {nd }}$ century. ${ }^{77}$

A deeper platter with a highly raised omphalos was uncovered at Regensburg-Kumpfmühl in the cellar of a building destroyed in the Marcomannic wars. ${ }^{78}$ Numerous parallels of this type are known from Cambodunum, ${ }^{79}$ Rainau-Buch, Niederbieber ${ }^{80}$ and from the Pudding Pan Rock. ${ }^{81}$ The production of this variant can be traced from the middle of the $2^{\text {nd }}$ century until the end of the century. ${ }^{82}$ Parallels of platters No. 14 and 15 are present in the Cambodunum assemblage and in the material from the $2^{\text {nd }}$ period of Regensburg-Kumpfmühl. The production of this type began in the $160 \mathrm{~s} .{ }^{83}$

No. 16. ("Präsentierplatte") indicates characteristics of the Niederbieber $1 \mathrm{c}$ form, with its mild distinction and convex wall. This type was produced mostly at Rheinzabern; however, our vessel is from Central Gaul. The production of this form can be traced from the 160 s onwards. ${ }^{84}$

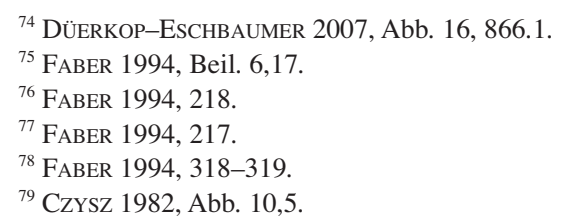

\footnotetext{
${ }^{80}$ DÜERKOP-Eschbaumer 2007, 65.

${ }^{81}$ Pudding Pan Rock 278, Nr. 11.

${ }^{82}$ DÜERKOP-EsCHBAUMER 2007, 65.

${ }^{83}$ FABER 1994, 218.

${ }^{84}$ FABER 1994, 219
} 
Drag. 33 form had an extraordinarily long life; it is present already in the form repertoire of Italian sigillata and among early Southern Gaulish ware. Phases of its development were formulated by M. Polak, ${ }^{85}$ while its late variants, surviving as late as the $4^{\text {th }}$ century, were presented by B. Pferdehirt. ${ }^{86}$ This form is not frequent until the middle of the $2^{\text {nd }}$ century it is surmounted by Drag. 27 type in quantity. However, by $170 / 180$, this type became the most frequent cup form, evidenced by numerous, well-dated deposits. ${ }^{87}$

Based on their formal features, the seven Drag. 33 form cups of the Papkeszi deposit can be divided into two groups. The larger - semipedalis - sized items are paralleled by the Niederbieber 9 type. These can be found in the material of the $7^{\text {th }}$ phase at Köln-Alteburg; that is, they can be dated to between 160 and the turn of the $2^{\text {nd }}-3^{\text {rd }}$ centuries. ${ }^{88}$ The smaller type, with a diameter of about $10 \mathrm{cms}$, is represented by two examples. Based on the evidence of parallel forms from Regensburg-Kumpfmühl, this type became widespread in the $170 \mathrm{~s} .{ }^{89}$ Close relatives of this type can be found in the cache find from Gorsium, which we could date to around 178.

There are no Drag. 32 type plates in the cache find. This form is also absent from the material in the fort period at Regensburg-Kumpfmühl. ${ }^{90}$

Three of the stamps have parallels in material from Pannonia: the one of Borillus at Baláca and Aquincum, that of Gippus at Aquincum and Gorsium, and that of Tittius at Gorsium. ${ }^{91}$

Certain of the sigillata cache finds, such as the finds from Eschenz, ${ }^{92}$ Baden,,${ }^{93}$ Vindonissa, ${ }^{94}$ Mainz ${ }^{95}$ and Neuss, ${ }^{96}$ Noviomagus,${ }^{97}$ Colchester, ${ }^{98}$ Corbridge ${ }^{99}$ and Wroxeter ${ }^{100}$ support the idea that they were pottery shops that also traded samian. The most well-known deposit is from Pompeii: this is a case full of relief-decorated vessels from La Graufesenque, which was buried together with the town by the ash from Vesuvius, before it could be opened. ${ }^{101}$ Deposits closer to Pannonia were found at Brigantium, ${ }^{102}$ Cambodunum, ${ }^{103}$ Burghöfe ${ }^{104}$ and Gauting. ${ }^{105}$

\section{THE CACHE OF PAPKESZI AND THE MARCOMANNIC-SARMATIAN WARS (166-180)}

The cache of Papkeszi and its closest parallel in space and time, the one from Gorsium indicate that they were both purposely hidden deposits. However, while the vessels of Gorsium were found in a building which was destroyed in the course of the Marcomannic wars, the depot from Papkeszi was only hidden during the same period. The destruction of certain buildings in the course of barbarian attacks can also be assumed, for good reason, in the case of the villa in nearby Baláca: a burnt, charcoal layer dated by Cinnamus's sigillata indicates that certain buildings at Baláca may have fallen victim to the invasion. ${ }^{106}$ In respect of the background of secondarily burnt Antonine samian, we had already presumed events of the Marcomannic wars to have been represented in the case of Baláca

${ }^{85}$ POLAK 2000, 121-123.

${ }^{86}$ PFERDEHIRT 1976, 77-80.

${ }^{87}$ K. KoRTÜM: Portus-Pforzheim. Untersuchungen zur Archäologie und Geschichte in römischer Zeit. Quellen und Studien zur Geschichte der Stadt. Pforzheim 3. Sigmaringen 1995, 278-280, 282; DÜERKOP-ESCHBAUMER 2007, 88.

${ }^{88}$ DÜERKOP-ESCHBAUMER 2007, 439.

${ }^{89}$ FABER 1994, 230.

${ }^{90}$ FABER 1994, 224; FisCHER 1994, 344

${ }^{91}$ GABLER 1994, 366.

${ }^{92}$ H. URnER-Astholz: Die römerzeitliche Keramik aus Eschenz-Tasgaetium. Thurgauische Beiträge zur vaterländischen $\mathrm{Ge}-$ schichte 78 (1942) 24ff.

${ }^{93}$ ETTLINGER 1969-1970, 82ff.

${ }^{94}$ E. EtTLinger: Ein Sigillata-Depotfund aus dem Legionslager Vindonissa. Germania 33 (1955) 364ff.

${ }^{95}$ W. vON PFEFFER: Ein kleines Sigillata Depot aus Mainz. Mainzer Zeitschrift 56-57 (196-1962) 209.

${ }^{96}$ Sels'sche Ziegelei. BJb 101 (1897) 1ff.

${ }^{97}$ C. G. A. Morren: Een terra sigillata Handelaar te Nijmegen. Numaga 13 (1966) 223-232.
${ }^{98}$ M. R. HuLL: Roman Colchester. Reports of the Resarch Committee of the Society of Antiquaries of London 20. London 1958, $153 \mathrm{ff}$.

${ }^{99}$ F. HAVERFIELD: An Account of the Roman Remains in the Parish of Corbridge-on Tyne. Oxford 1914, 490-492.

${ }^{100}$ D. ATKinson: Report on Excavations Wroxeter (the Roman City of Viroconium) in the County of Salop 1923-1927 . Oxford 1942, 56-58; G. MACDonALD: Forschungen im römischen Britannia 1914-1924. BRGK 19 (1929) 70-71.

${ }^{101}$ D. AtKInSON: A hoard of Samian ware from Pompeii. JRS 4 (1914) 27-64.

${ }^{102}$ J. JACOBS: Sigillatafunde aus einem römischen Keller zu Bregenz. JfA 6 (1912) 173ff.

${ }^{103}$ CZYSZ 1982, 339-340.

${ }^{104}$ G. Ulbert: Die römischen Donaukastelle Aislingen und Burghöfe. Limesforschungen 1. Berlin 1959, 55.

${ }^{105}$ N. WALKE-I. WALKE: Reliefsigillata von Gauting. BRGK 46-47 (1965-1966) 77ff.; T. FISCHER: Zur Chronologie der römischen Fundstelle um Regensburg. BVbl 46 (1981) 70.

${ }^{106}$ D. GABLER: A balácai terra sigillaták (The terra sigillate from Baláca) 2. BalácaiKözl 2 (1992) 296; D. GABLER: Die Sigillaten von Baláca. 4. BalácaiKözl 7 (2002) 69-107. 
as well. ${ }^{107}$ Nevertheless, in the absence of extensive destruction layers, the destructions of the Marcomannic wars at Baláca should be treated as a working hypothesis; it could not eventually have related to the main building (building I.), as that was one which was constructed in a later period. ${ }^{108}$

Among finds indicating the destructions of the Marcomannic wars, A. Faber regarded the samian products from Lezoux and, to some extent, those from Rheinzabern as dominant types, as it was also the case at RegensburgKumpfmühl. ${ }^{109} \mathrm{~A}$ destruction layer dated to around 170 was also observed in the camp of Böhming, containing the earliest Rheinzabern sigillata besides the ware of Cinnamus. ${ }^{110}$

Based on the secondarily burnt samian (mostly Lezoux and early Rheinzabern, Bernhard I a group) found at Mangolding/Mintraching, T. Fischer came to the conclusion that the settlement was destroyed by the barbarians in the Marcomannic wars. ${ }^{111}$ In the Western fort of Straubing, the destruction layer observed in the barracks and the fort ditches (III a) was related to the events of the Marcomannic wars. ${ }^{112}$

Deposits from the same era emerged also in Noricum. At Salzburg (Juvavum), Central Gaulish and Rheinzabern sigillata was found in the filling of a well, which can be dated by a coin minted in 170/171. ${ }^{113}$ Based on excavation results and its finds, W. Kovacsovics dated the extensively observed destruction layer (seen in ten locations at least) to around 170, and related the layer to the Marcomannic wars. ${ }^{114}$ The greater part of Cetium (St. Pölten) might have been destroyed in the same period, as is also evidenced by destruction layers, ${ }^{115}$ the excavator describes the destruction of mostly wooden constructions by a fire. These results were criticized by $\mathrm{Ch}$. Hinker, ${ }^{116}$ who referred to the lack of such a catastrophe horizon at nearby Mautern, although the end of the vicus's $3^{\text {rd }}$ period can be dated to around $170 .{ }^{117}$ Of course, this does not refute historically related consequences, which were based on observations at the Cetium excavations.

In the south-eastern part of Noricum, Flavia Solva is the only settlement containing a destruction layer (in XLI insula) that can be dated to around 170 . The dating is evidenced by coins and terra sigillata. ${ }^{118}$ Still, Ch. Hinker asserts that an actual destruction horizon coincides with the period of the Marcomannic wars. ${ }^{119}$ However, the archaeologically evidenced causes of the fire can only be taken as a probability, and the fire could also be attributed to an accidental, "Schadenfeuer" catastrophe. All in all, more explanations should be considered. ${ }^{120}$ We cannot accept his far-fetched criticism, although we admit that he may be right in stating that the relation between the destruction layers and the Marcomannic wars cannot be clearly established in many cases of villas or settlements at Noricum (see the destruction layer of the villa at Grünau). ${ }^{121}$ Decorated samian vessels in XLI insula from Flavia Solva were produced by potters who are almost identical with the ones who made the bowls of the so-called pottery shop in the civic town of Aquincum, ${ }^{122}$ which was connected with the destruction in the years 178/179. This means that in regard to the samian, a period of 8-9 years does not indicate a considerable change in the spectrum of finds. A destruction layer

2014,114

${ }^{107}$ GabLER-PALÁGYi 1989, 111. Its critique, see. HinKER

${ }^{108}$ S. PALÁGYI: Schwerpunkte der neuen Ausgrabungen im Gutshof von Baláca. BalácaiKözl 3 (1994) 10-21.

${ }^{109}$ FABER 1994, 191ff.; FISCHER 2012, 35.

${ }^{110}$ B. GNADE: Das römische Kastell Böhming am Raetischen Limes. Bericht der Bayerischen Denkmalpflege 51 (2010) 240, 242; FisCHER 2012, $32 \mathrm{ff}$.

${ }^{111}$ T. FISCHER: Das Umland des römischen Regensburg. MBV 42/1. München 1990, 48.

${ }^{112}$ J. Prammer: Das römische Straubing. Ausgrabungen, Schatzfund, Gäubodenmuseum. Bayerische Museen 11. München 1989, 23, 35; FISCHER 1994, 345; FISCHER 2012, 34.

${ }^{113}$ M. SEEBACHER: Römisches aus einem Brunnen unter einer Zisterne in der sog. Dietrichsruh in Salzburg. JÖAI 68 (1999) 266, 268.

${ }^{114}$ W. K. Kovacsovics: Juvavum. In: Die autonomen Städte in Noricum und Pannonia. Hrsg.: M. Šašel Kos, P. Scherrer. Situla 40. Ljubljana 2002, 171, 186; W. K. Kovacsovics: Iuvavum Neue Beobachtungen zur Struktur der römischen Stadt. In: Die norisch-pannonische Städte und das römische Heer im Lichte der neuesten archäologischen Forschungen. II. Int. Konferenz über norisch- pannonische Städte, Budapest-Aquincum 11.-14. September 2002 Hrsg.: L. Borhy, P. Zsidi. Budapest 2005, 149.

${ }^{115}$ P. SCHERRER: Cetium. In: Die autonomen Städte in Noricum und Pannonien. Hrsg.: M. Šašel Kos, P. Scherrer. Situla 40. Ljubljana 2002, 226; earlier P. SCHERRER: Kurzer Bericht über die Ausgrabungen auf dem Rathausplatz 1988/89. In: P. Scherrer: Landeshauptstadt St. Pölten. Archäologische Bausteine. SÖAI 22. Wien 1991, 81, 84; P. SCHERRER: Bericht über die Bausteine. SÖAI 22. Wien $1991,107$.

${ }^{116}$ HINKER 2014, 197.

${ }^{117}$ ST. GROH: Keramikprodukte. 1.: Terra Sigillata. In: St. Groh-H. Sedlmayer: Forschungen im Vicus Ost von Mautern-Favianis. Die Grabungen in der Jahre 1997-1999. RLÖ 44. Wien 2006, 234.

${ }^{118}$ ST. GROH: Die Insula XLI von Flavia Solva. Ergebnisse der Grabungen 1959 und 1989 bis 1992. SÖAI 28. Wien 1996, 179-181.

${ }^{119}$ HINKER 2014, 175.

${ }^{120}$ HINKER 2014, 188

${ }^{121}$ S. LAMM: Die Villa rustica von Grünau. Zwischenbericht eines Dissertationsprojektes (Stand Jänner 2009). Tagungsbericht Symposium Die archäologische Erforschung römischer Villen im Ostalpenraum in Södingberg 2008. FÖ 48 (2009) 107-115.

${ }^{122}$ GABLER-KOCZTUR 1976, 75. 
was observed also in the vicus of Kalsdorf, which could be dated to 170-180 on the basis of wares of Laxtucissa and Censorinus. According to U. Lohner-Urban, who published the finds, even though the destruction layer can be explained by the events of the Marcomannic wars, she still rejects the conclusions as to this topic. ${ }^{123}$ At Carnuntum, based on the samian ware, the destruction layer of the first stone fort of the auxiliary fort of Petronell can be related to the Marcomannic wars. This assemblage is also dominated by products from Central Gaul (mostly by bowls of Cinnamus), while there is a lack of early Rheinzabern ceramics. ${ }^{124}$ At the same time, in the legionary fortress or the canabae, archaeological phenomena which could be related to these events are missing. ${ }^{125}$ Traces of burning can be observed at Salla as well, ${ }^{126}$ dated by secondarily burnt Antonine samian from Lezoux and Eastern Gaul. ${ }^{127}$ The pattern of coin circulation can also be related to events of the Marcomannic wars in this town located on the Amber Road. ${ }^{128}$

In Savaria, such a destruction layer was not observed within the town; although in the ditches around the town wall there was a charcoal filling, the chronological sequence of this layer is uncertain. The city wall was probably strengthened during or after the raids in $170 .{ }^{129}$ Coin hoard closing with mintings from the year 177 can probably be related to later events of the war, namely the invasion in $178 .{ }^{130}$

Along the Savaria-Arrabona route, branching off from the Amber Road, destruction layers dated by Antonine terra sigillata could be observed at two sites. At Mursella, the sequence of the destruction layer was dated with the help of Cinnamus's sigillata. ${ }^{131}$ An Antonine sigillata from Central Gaul was found in a pit filled with remains of the originating from the wooden construction of the mansio charcoal-ash ember and clay cob of the mansio of Sárvár (Q 58/60); this supports the suggestion that the clay floor of the wooden building was burnt in a fire that can be dated to around 170. ${ }^{132}$ At Ács-Vaspuszta, a layer filled with burnt material furnishes evidence that the destruction of the earth-timber fort II related to the Marcomannic wars. ${ }^{133}$ Similar observations could be made in the fort and vicus of Arrabona /Györ, in the castellum of Quadrata /Lébény-Barátföldpuszta, and on the basis of parallel phenomena, we may further surmise that the destruction also involved Gerulata (Oroszvár, Rusovce). ${ }^{134}$ Deposits from Gorsium and Aquincum can be related to the Germanic-Sarmatian attacks of 178/179, ${ }^{135}$ which, among others, resulted in the destruction of the earth-timber fort of Celamantia (Izsa-Leányvár). ${ }^{136}$ Among the samian from Leányvár there were slightly more products of the Antonine period from Rheinzabern than from Lezoux.

${ }^{123}$ U. LOHNER-URBAN: Untersuchungen im römischen Vicus von Kalsdorf bei Graz. Die Ergebnisse der Ausgrabungen auf der Parzelle 421/1. Baubefunde und ausgewählte Kleinfunde. Forschungen zur geschichtlichen Landeskunde der Steiermark 50. Wien 2009, 169

${ }^{124}$ S. JiLEK: Ein Zerstörungshorizont aus der 2. Hälfte des 2. Jahrhunderts n.Chr. im Auxiliarkastell Carnuntum. In: Markomannnenkriege - Ursache und Wirkungen. 6. Internationales Symposium „Grundprobleme der frühgeschichtlichen Entwicklung im nördlichen Mitteldonaugebiet“. Hrsg.: H. Friesinger, J. Tejral, A. Stuppner. Brno 1994, 392-394; M. KROMBERGER: Ausgewähltes keramisches Fundmaterial aus stratifizierten Fundkomplexen. In: Das Auxiliarkastell Carnuntum. 1. Hrsg.: H. Stiglitz. SÖAI 29. Wien 1997, 85-86.

${ }^{125}$ M. KANDLER: Carnuntum. In: Die autonomen Städte in Noricum und Pannonien. II. Hrsg.: M. Šašel Kos, P. Scherrer. Situla 42. Ljubljana 2004, 18 .

${ }^{126}$ F. REDŐ: Municipium Aelium Salla. In: Die autonome Städte in Noricum und Pannonien. Hrsg.: M. Šašel Kos, P. Scherrer. Situla 40. Ljubljana 2003, 208, 212.

${ }^{127}$ D. Gabler: Terra Sigillata. In: RFiZ 1975. ActaArchHung 29 (1977) 241ff.; GABLER 1994, 356.

${ }^{128}$ F. REDŐ: Strategic significance of Salla and its effects on the development of the inner Pannnonian municipium. In: Die norisch-pannonische Städte und das römische Heer im Lichte der neuesten archäologischen Forschungen. II. Int. Konferenz über norischpannonische Städte, Budapest-Aquincum 11.-14. September 2002 Hrsg.: L. Borhy, P. Zsidi. Budapest 2005, 143.

${ }^{129}$ T. BuOCZ-D. GABLER: Savariai városfal [The City Wall of Savaria]. Sárvár 2002, 22, 130.

${ }^{130}$ K. BírÓ SEY: A szombathelyi koracsászárkori éremlelet (Ein Depotfund aus der frühen Kaiserzeit in Szombathely). FolArch
12 (1960) 75-89; M. KÖHEGYI: Megjegyzések és pótlás két szombathelyi II. század végi dénárlelethez (Notes and addenda to two denar finds from Savaria). Savaria 4 (1966-1970) 97-103. On the events of year 178, see KovÁcs 2009, 285.

${ }^{131}$ E. SzŐNYI: Kutatások Mursellában. Beszámoló az Árpás-Dombi földön 1975-1980 között végzett feltárásokról (Ausgrabungen in Mursella). ComArchHung 1981, 94, 110.

${ }^{132}$ D. GABLER: Römische Straßenstation in der Gemarkung von Sárvár. ComArchHung 1991, 50ff.; D. GABLER: Die römische Straßenstation von Sárvár und ihre Vorgängerbauten aus dem 1. Jahrhundert n.Chr. Carnuntum Jb 1997, 40, 56.

${ }^{133}$ D. Gabler: The Roman Fort at Ács-Vaspuszta (Hungary) in the Danubian Limes. BAR IntSer 531. Oxford 1989, 32, $248 f$.

${ }^{134}$ GABLER: 1994, 358.

${ }^{135}$ T. NAGY: Buda régészeti emlékei [The archaeological monuments of Buda]. In: Budapest müemlékei. II. Ed.: M. Horler. Magyarország müemléki topográfiája 6. Budapest 1962, 45, 97.

${ }^{136}$ J. RAJTÁR: Das Holz-Erde Lager aus der Zeit der Markomannenkriege. In: Probleme der relativen und absoluten Chronologie der Latenezeit bis zum Frühmittelalter. Grundprobleme der frühgeschichtlichen Entwicklung im nördlichen Mitteldonaugebiet. Hrsg.: K. Godłowski, R. Madyda Legutko. Kraków 1992, 162, 164, Abb. 16,2-7; G. Domański: Die Frage des Zeithorizontes der Markomannenkriege in Barbaricum. In: Probleme der relativen und absoluten Chronologie der Latėnezeit bis zum Mittelalter. Hrsg.: K. Godłowski, R. Madyda Legutko. Kraków 1992, 130; K. KuZmová: Pottery from the earth-timber fort of Iža, bridgehead of Brigetio. Acta RCRF 35 (1997) 45, 47, Abb. 1 A. 
The same can be stated in the case of sigillata found in the destruction layer of the earth-timber fort's retentura at Intercisa. In the dating of the Antonine catastrophe, the evidence of a coin minted in 175 is of decisive importance. ${ }^{137}$

The majority of the samian vessels so far published from Mušov-Burgstall, which was used also as a military base during the Marcus wars, are Antonine ware from Lezoux (Cinnamus), with only a few of the early samian from Rheinzabern that can be classified to group Bernhard I. ${ }^{138}$ Among plain sigillata, the Drag. 32 form plate is missing from this site as well.

The few secondarily burnt Antonine samian vessels at Poetovio do not confirm unambigously the destruction of the town, and evidence confirming this claim is also lacking in the district of Aquileia, despite the records of historic sources as to the siege of the Adriatic town. ${ }^{139}$ Archaeological evidence is also missing in the case of the destroyed Opitergium/Oderzo. ${ }^{140}$

Previously, a sigillata deposit from Munningen was related to the destructions of the Marcomannic wars. ${ }^{141}$ However, following its comparison with the finds from Regensburg-Kumpfmühl, it turned out that the assemblage from Munningen can probably be dated to the period after $180 .{ }^{142}$ Earlier, the destructions of the villas of Juvavum and Mondsee were both declared to be the result of the Marcomannic wars. ${ }^{143}$ A. Krammer was more circumspect in connecting the destruction of the villa in a fire with the events of the war. ${ }^{144} \mathrm{G}$. Alföldy also expressed his concerns in connection with the destruction of the villa at Katsch as a result of a Germanic raid. ${ }^{145}$ The end of the first period of the Rannersdorf villa was dated to around 170-180, but there is no evidence to support the early villa having been abandoned as a result of the Marcomannic invasion. ${ }^{146}$ A direct connection also cannot be established between the destruction of the settlement at Gleisdorf and the Germanic raids. ${ }^{147}$ Previously, based on secondarily burnt Antonine sigillata, we presumed the presence of destruction layers in the civic town of Vindobona. This seemed to be supported elsewhere by sigillata and also two coin hoards ending with two coins of Antonius Pius, which were uncovered on the territory of Aspangbahnhof in the $3^{\text {rd }}$ district of Vienna ${ }^{148}$; however, the suggestion concerning the destruction of the civic town is not supported by such evidence.

Concerns had rightly been raised in the case of Brigetio concerning the destruction layers, the existence of which was surmised on the basis of secondarily burnt samian. ${ }^{149}$ The burnt basement feature observed in the territory of the vicus of Klosterneuburg and the material of a well-filling also cannot be related to the events of the Marcomannic wars. ${ }^{150}$

${ }^{137}$ B. LŐRINCZ-K. SZABÓ-Zs. VISY: Neue Forschungen im Auxiliarkastell von Intercisa. In: Studien zu den Militärgrenzen Roms. III. Stuttgart 1986, 363, 367.

${ }^{138}$ G. Domański: Die Frage des Zeithorizontes der Markomannenkriege in Barbaricum. In: Probleme der relativen und absoluten Chronologie der Latėnezeit bis zum Frühmittelalter. Grundprobleme der frühgeschichtlichen Entwicklung im nördlichen Mitteldonaugebiet. Hrsg.: K. Godłowski, R. Madyda Legutko. Kraków 1992, 130; E. DroberJaR: Die römische Keramik vom Burgstall bei Mušov, Mähren. ArchA 77 (1993) 46-44.

${ }^{139}$ KovÁcs 2009, 201-203.

${ }^{140}$ M. S. Busana: Oderzo forma urbis. Saggio di topografia antica. Roma 1995, 28; for the numismatical evidence see, P. PRoHÁszKa: Der römische Münzfund von Fara (1827) und die Zeugnisse des Germaneneinfalles nach Italien unter Kaiser Marcus Aurelius. ArchA 96 (2012) 95-100.

${ }^{141}$ D. BAATZ: Das Kastell Munningen, im Landkreis Donau-Ries. JBBD 15-16 (1974-1975) [1977] 108-120. - earlier: H. EIDAM: Das Kastell Munningen. Der obergermanische-rätische Limes des Römerreiches 68/a. Im Auftrage der Reichs-Limeskommission hrsg. von E. Fabricius. Berlin-Leipzig 1929, 13-14.

${ }^{142}$ FisCHER 1994, 347; FisCHER 2012, 29-44; CH. HINKER: Ein Brandhorizont aus der Zeit der Markomannenkriege im südostnorischen Munizipium Flavia Solva mit Beiträgen von G. Christandl, U. Schachinger. Zentraleuropäische Archäologie 4. Wien 2014, 116.
${ }^{143}$ A. Kaltenberger: Die Grabungen des Österreichischen Archäologischen Instituts in ehem Benediktinerkloster (,Schloss“ Mondsee). Römerzeit. JOÖMV 140 (1995) 14.

${ }^{144}$ A. KRAMMER: Ein mittelkaiserzeitlicher Zerstörungshorizont in Juvavum/Salzburg. Die Ausgrabungen im Furtwänglerpark in den Jahren 1987/88. BVbl 72 (2007) 44.

${ }^{145}$ G. AlFöLdY: Noricum. The provinces of the Roman Empire. London 1974, 153.

${ }^{146}$ B. SCHRETTLE-T. TSIRONI: Die Ausgrabungen der Jahre 2005 bis 2007 in der Villa Rannersdorf. Kaiserzeitliche und spätantike Funde und Befunde. FÖ 46 (2007) 237, 257.

${ }^{147}$ C. MAIER: Der Vicus von Gleisdorf. In: Der römische Vicus von Gleisdorf. Bericht über die Ausgrabungen 1988-1990. Hrsg.: T. Lorenz, M. Lehner, C. Maier. VIKA Graz 2. Wien 1995, 43.

${ }^{148}$ GABLER 1994, 356; there is no any traces of destruction in the legionary fortress of Vindobona, too, see M. MossER: Der Wiener Judenplatz und das Legionslager Vindobona. In: Die römischen Kasernen im Legionslager Vindobona. Die Ausgrabungen am Judenplatz in Wien in den Jahren 1995-1998. Monographien der Stadtarchäologie Wien 5. Wien 2010, 32.

${ }^{149}$ T. BECK: Terra Sigillata in Brigetio. Vorbericht zu den Funden der Grabungen 1992-1996. In: Die autonomen Städte in Noricum und Pannonien. Pannonia II. Hrsg.: M. Šašel Kos, P. Scherrer. Situla 42. Ljubljana 2004, 245.

${ }^{150}$ J. W. NEUGEBAUER: Vom römischen Lagerdorf zum mittelalterlichen Lesehof. Katalog des Stadtmuseums Klosterneuburg. Wien 1998, 26ff. For its refutation, see HINKER 2014, 174. 
None of the above-presented vessels found at Papkeszi have traces of burning; in contrast, every single one of the terra sigillata found at Tác (Gorsium) were burnt black secondarily, similarly to the relief-decorated items from Baden (Aquae Helveticae). ${ }^{151}$ The classification of the assemblage corresponds to the one at the Gorsium depot, which has similarly more of the catillus, paropsis and acetabulum, although our depot has only fragments of the big "Präsentierplatte". This trichotomy corresponds to the general custom, which is attested by data from papyri, precious metals and grave lots alike. ${ }^{152}$ The stamps, or rather those potters represented by stamps, from Lezoux also differ from each other. In the cases of the 18 Gorsium and 12 Papkeszi signaturae, only Gippus and Tittius are the same.

\section{GRAFFITI ON SAMIAN AND THE OWNER OF THE SET}

We managed to identify 12 graffiti on vessels of the 15-piece terra sigillata set. It is not a surprise that inscriptions are most likely to be found on the more expensive, imported terra sigillata: among all ceramic types this one has the highest overall quantity of graffiti. ${ }^{153}$ With the exception of vessels in the depot find, none of the numerous terra sigillata or other ceramic fragments from Papkeszi has graffiti on them.

Vessels of the terra sigillata set from Papkeszi have the following graffiti (Table 1; Fig. 9-10):

1. On the bottom's back of Drag.33 form cup with stamp ALBVCI (Inv. No.: HNM RR 2015.1.1), there is a graffiti inside the foot ring (Fig. 9.1). Parameters of the radiately, inward positioned capital letters of the not very accurately scratched inscription: $\mathrm{V}=0.85 \mathrm{cms} ; \mathrm{E}=0.9 \mathrm{cms} ; \mathrm{R}=(0.7) \mathrm{cms} ; \mathrm{I}=(0.9) \mathrm{cms}$. The left bar of $\mathrm{V}$ runs longer downwards than the left one, they are not connected in an apex. The lower horizontal bar of $\mathrm{E}$ is short; the vertical bar of $\mathrm{R}$ was cut by two strokes forming an angle with each other. The sequence of the letters is consistent and dense. The upper horizontal bar of the $\mathrm{E}$ and the bowl of the $\mathrm{R}$ is broken and lost. The inscription reads:

VERI.

2. The Drag.33 form cup with an ATICI-SO I stamp (Inv. No.: HNM RR 2015.1.2) bears a graffiti on the lower part of the outer surface of the side wall (Fig. 9.2). The inscription is written by not very precisely scratched letters, their height parameters: $\mathrm{V}=0.9 \mathrm{cms} ; \mathrm{E}=1.1 \mathrm{cms} ; \mathrm{R}=1.3 \mathrm{cms} ; \mathrm{I}=1.2 \mathrm{cms}$. The sequence of the letters is consistent and less condense. The counter is $0.8-0.9 \mathrm{cms}$. The bars of $\mathrm{V}$ are not connected in the apex, its right bar is scratched by two parallel lines. The lower horizontal bar of the $\mathrm{E}$ is shorter than the upper one; its vertical bar, cut from the top downwards, extends over the lower horizontal bar of the letter. The vertical bar of the $\mathrm{R}$ was cut by using three strokes, its bowl extends over the vertical line by slanting to the left. The inscription reads:

VERI.

3. On the side of a Drag.33 form cup with a BORILLI OF stamp (Inv. No.: HNM RR 2015.1.3), 0,3 cms above the horizontal line scratched in the middle, there is a graffiti consisting of three letters (Fig. 9.3). The inscription bears three, not very precisely formed capital letters, $\mathrm{D}=0.9 \mathrm{cms} ; \mathrm{V}=1.2 \mathrm{cms} ; \mathrm{M}=0.8 \mathrm{cms}$. The sequence of the letters is dense, with a small counter. The bowl of D broadens towards the lower side in a triangular shape; the left bar of $\mathrm{V}$ is longer than the right one. The first two strokes of the $\mathrm{M}$ are not connected, while the third one extends over the fourth stroke on the edge. The inscription reads:

$D V M$.

4. On the backside of a Drag.18/31 form plate with stamp CRISTOF (Inv. No.: HNM RR 2015.1.4), outside, but adjusted inside the foot ring, there is a graffiti (Fig. 9.4). The inscription is written by radially standing, not very accurately executed, but clear-cut capital letters of different sizes, $\mathrm{V}=1.2 \mathrm{cms} ; \mathrm{E}=1.5 \mathrm{cms} ; \mathrm{R}=1,3 \mathrm{cms}$; $\mathrm{I}=1.4 \mathrm{cms}$. The grooves are narrow and shallow. The bars of the $\mathrm{V}$ are not connected, horizontal bars of the $\mathrm{E}$ are

${ }^{151}$ ETTLINGER 1969-1970, 83.

${ }^{153}$ BILKEI 1985, 12; BARTA 2006, 123

${ }^{152}$ GABLER-KOCZTUR 1976, 79 

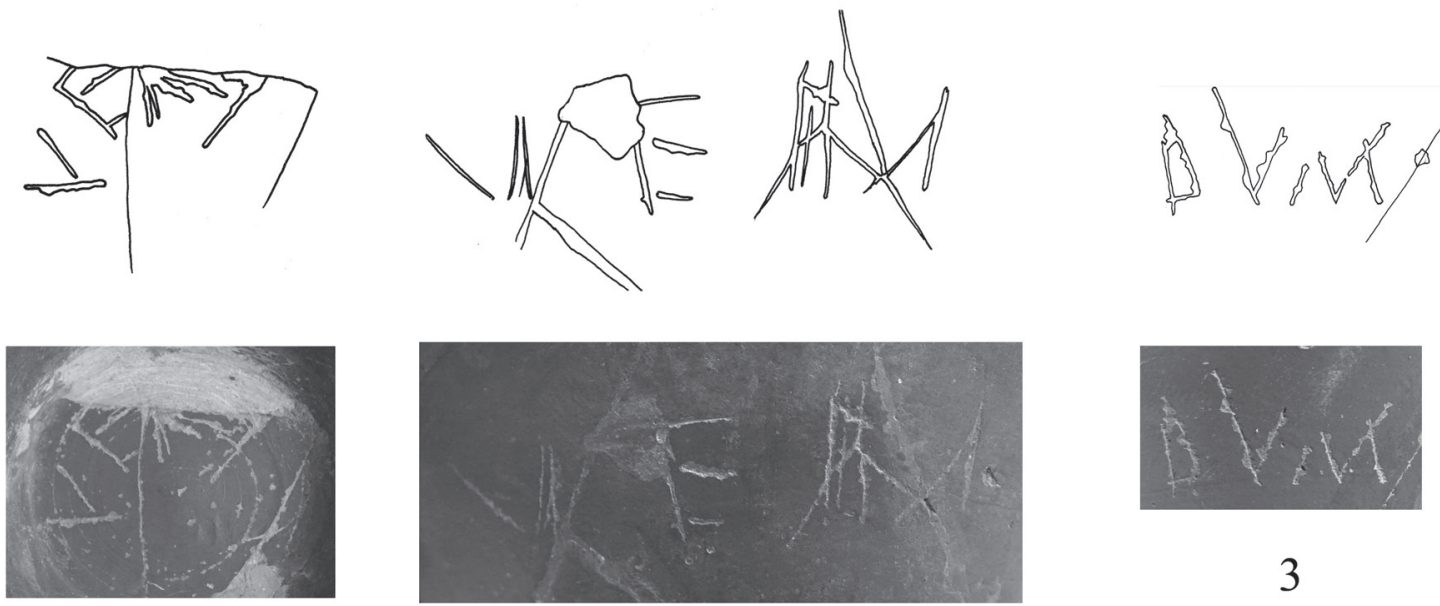

1

2
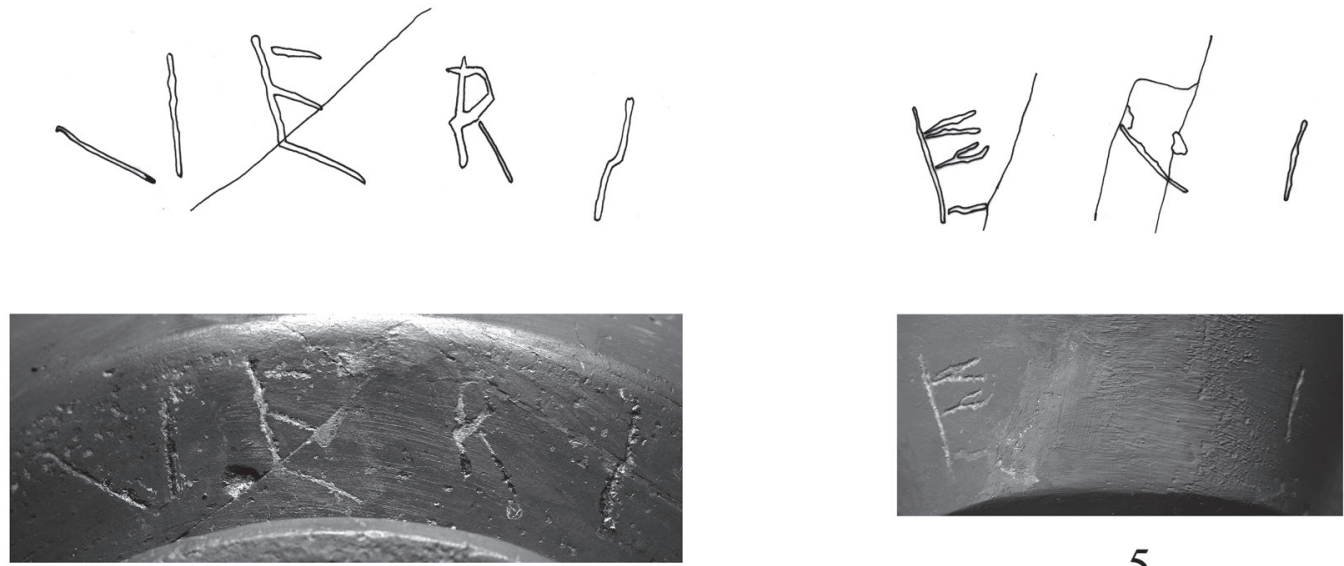

4

5
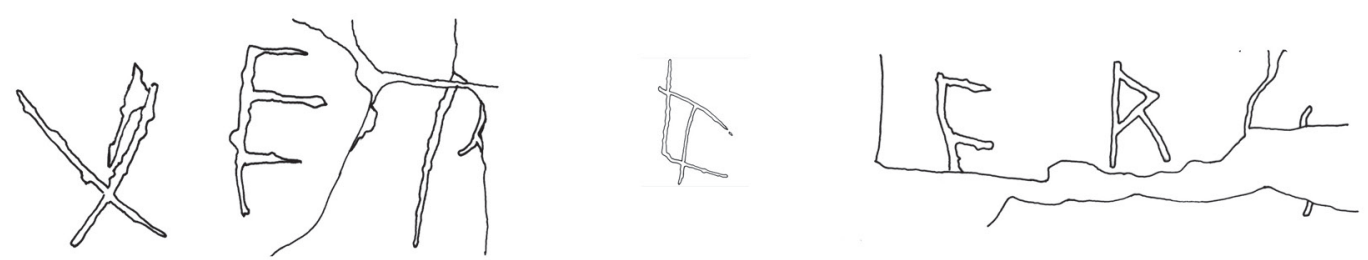

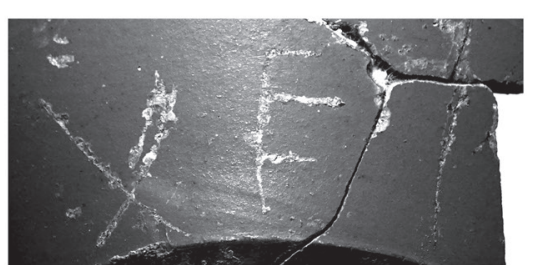

6

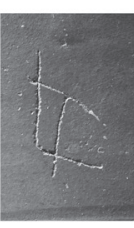

7

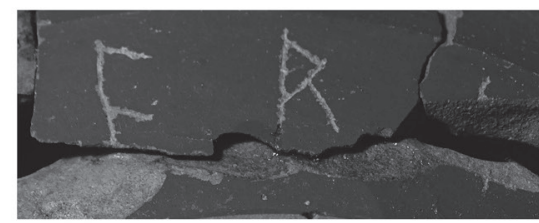

8

Fig. 6. Papkeszi, graffiti on the vessels of the terra sigillata deposit. 1: Cat. 1; 2: Cat. 2; 3: Cat. 3; 4: Cat. 4; 5: Cat. 6; 6: Cat. 7; 7: Cat. 8; 8: Cat. 9 

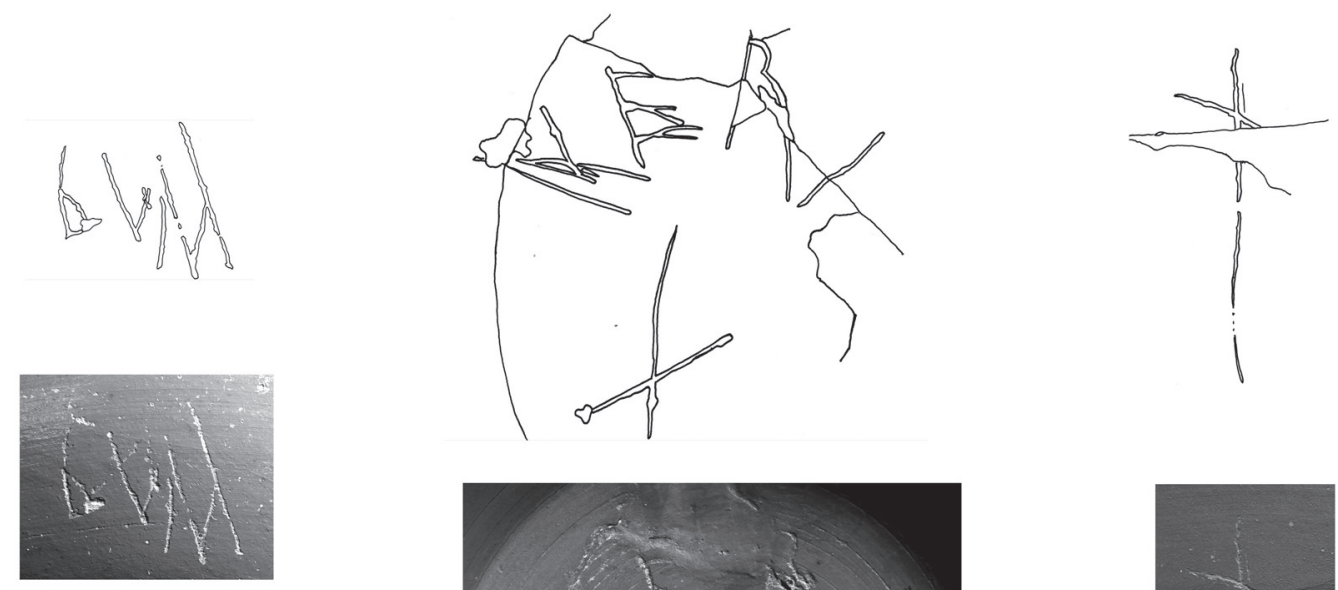

1
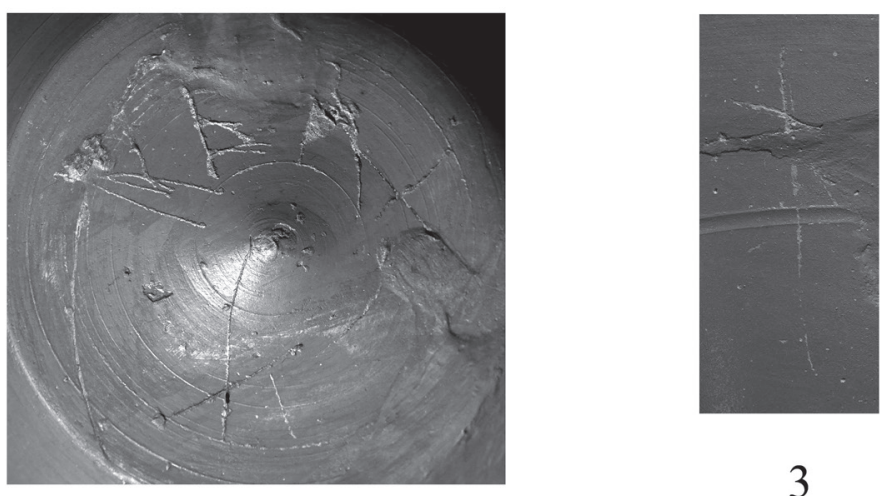

3

2

Fig. 7. Papkeszi, graffiti on the vessels of the terra sigillata deposit. 1: Cat. 10; 2: Cat. 11; 3: Cat. 13

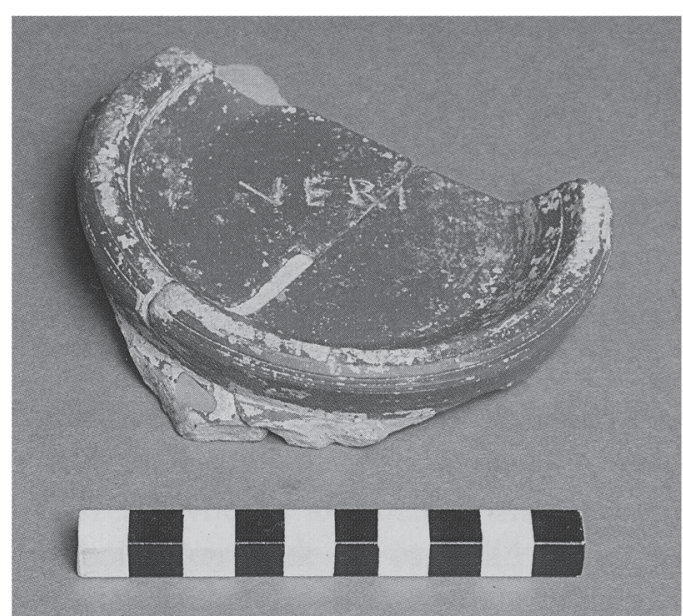

1

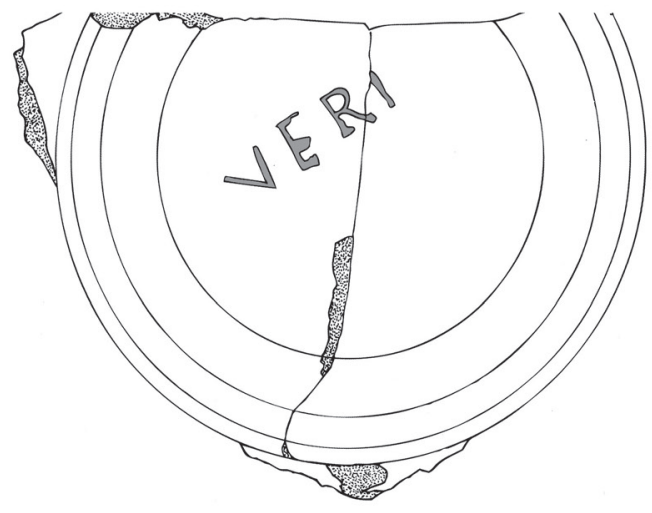

2

Fig. 8. Páty, Malom-dủlő. Terra sigillata fragment with VERI graffiti 

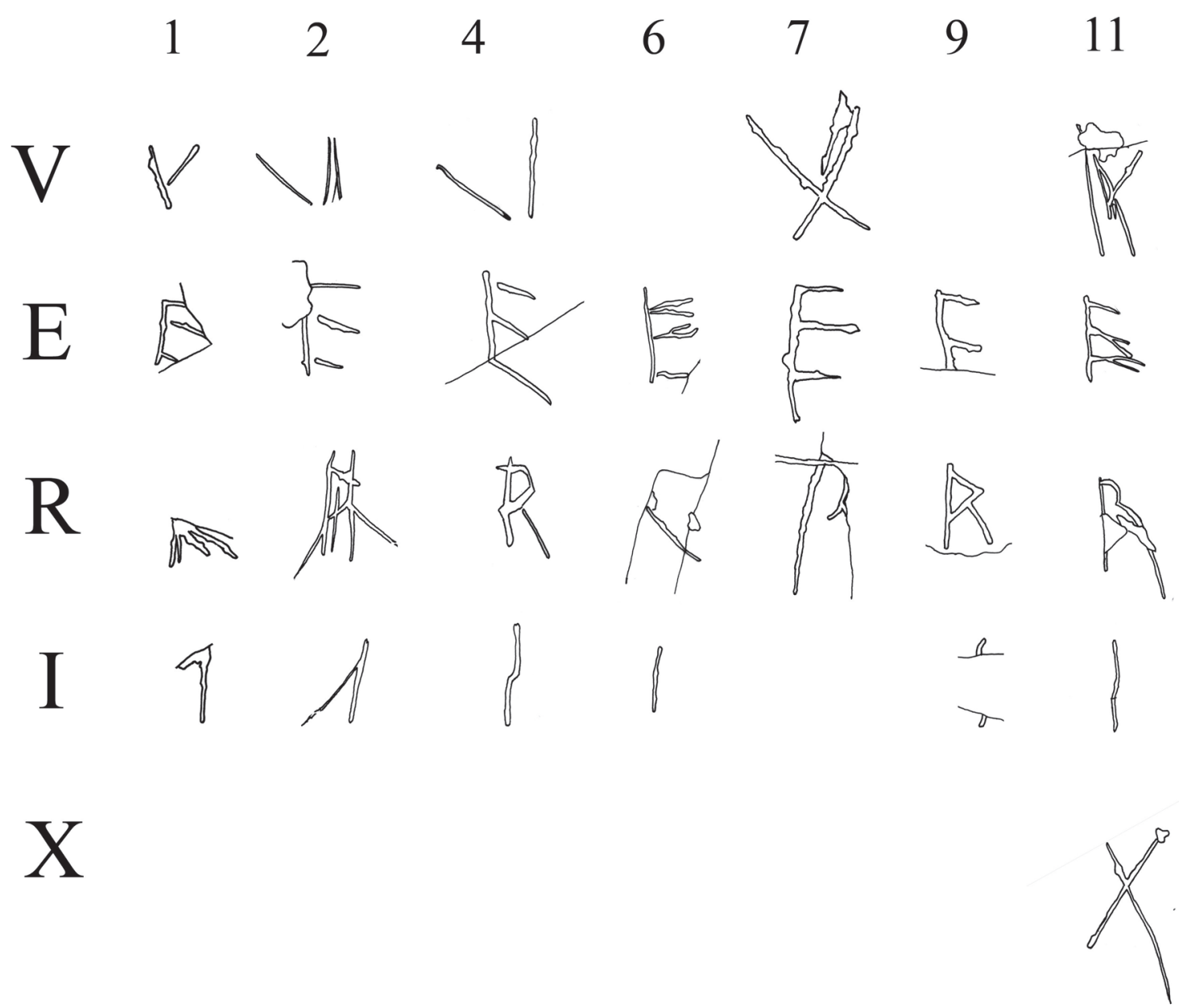

Fig. 9. Papkeszi. The font set of the vessels with VERI graffiti

slanting downwards, and the lower one is a bit longer; the upper bowl of R is square (Fehér 2013, R/a type). The inscription reads:

VERI.

5. There was no visible inscription on the available fragments of the Drag. $18 / 31$ form which is a strongly fragmented plate with stamp GIPPI·M (Inv. No.: HNM RR 2015.1.5).

6. On the outer surface of the sidewall of the Drag. 33 form cup with stamp PAVLIM (Inv. No.: HNM RR 2015.1.6), there is a scratched inscription close to the angle between the side wall and the base (Fig. 9.5). The inscription was written by not very precisely formed letters of various heights: $\mathrm{E}=1.2 \mathrm{cms} ; \mathrm{I}=0.8 \mathrm{cms}$. The letters follow each other in a consistent sequence and have a significant counter. The vertical bar of the E extends both the upper and lower horizontal bar of the letter, its horizontal upper and middle bars were cut by two strokes. Vessel fragment containing letter $\mathrm{V}$ is absent. In its current form the inscription reads:

[V]ERI.

7. On the sidewall of a Drag.33 form cup with stamp PAVLIM (Inv. No.: HNM RR 2015.1.7), there is a graffiti on the surface above the angle between the side wall and the base (Fig. 9.6). The capital letters of the inscription are not written with great accuracy, $\mathrm{V}=1.6 \mathrm{cms} ; \mathrm{E}=1.35 \mathrm{cms} ; \mathrm{I}=1.25 \mathrm{cms}$. Both bars of $\mathrm{V}$, after crossing each 


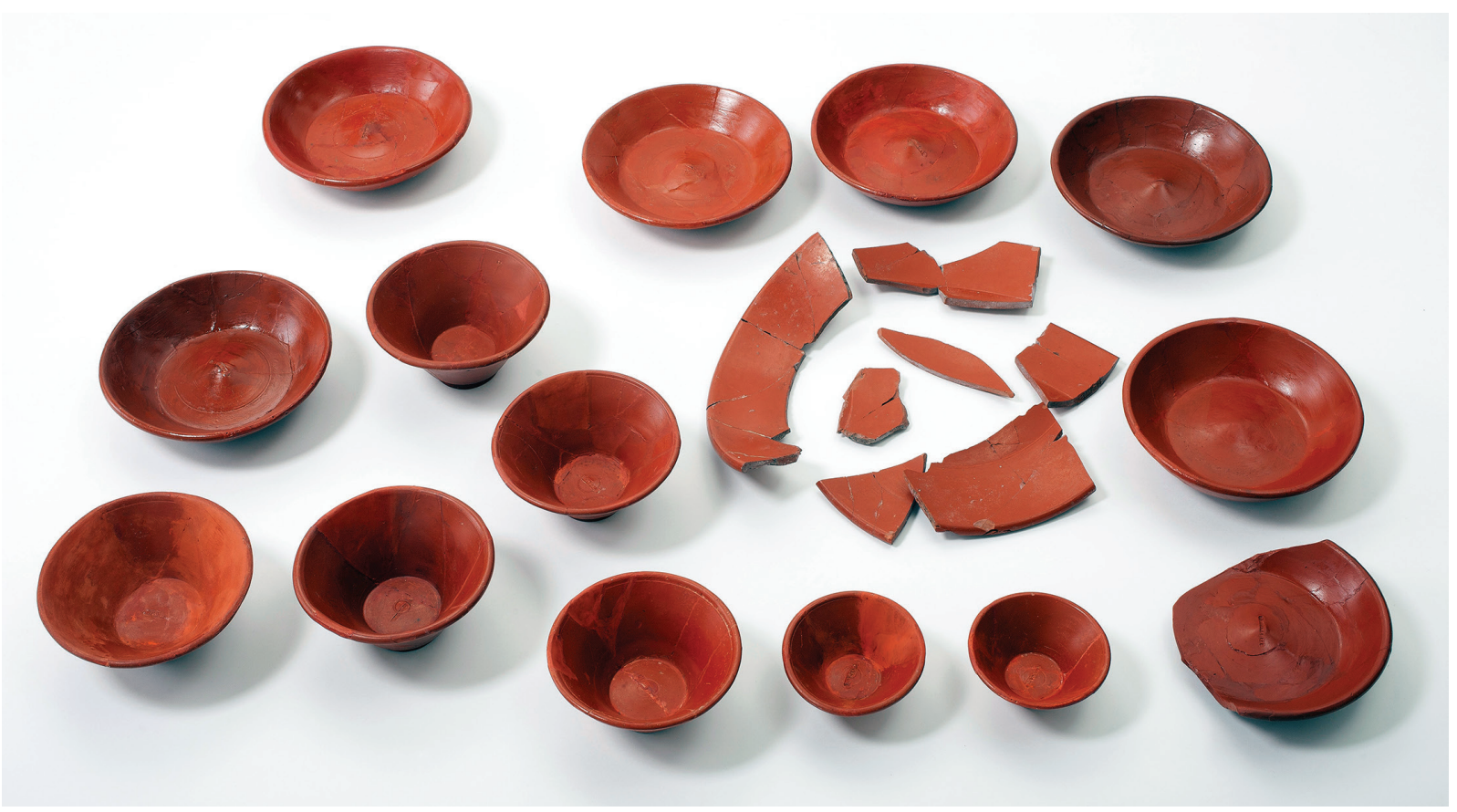

Fig. 10. The samian cache from Papkeszi (photo: József Rostás, Hungarian National Museum)

other, extend over the apex; the vertical bar of the E extends over the lower horizontal bar downwards; the R is fragmented. The sequence of the letters of the inscription is consistent, the counter is $0.7 \mathrm{cms}$. The inscription reads: VER[I].

8. A scratched character consisting of two letters crossing each other is visible on the outer side wall of the Drag.33 form cup with stamp REBVRRI.OF (Inv. No.: HNM RR 2015.1.8). It is located below the rim and above the horizontal line running along the middle of the vessel, placed closer to the latter (Fig. 9.7). The character is written by not very accurately formed letters, $\mathrm{L}=1.2 \mathrm{cms} ; \mathrm{T}=1.1 \mathrm{cms}$. The bar of $\mathrm{T}$ is oblique, its crossbar is also oblique and was scratched with a slightly curved line. The most probable reading of the letters is:

\section{$L T$.}

9. An inscription was scratched on the outer wall of a Drag.18/31 form plate with a REBVRRI OF stamp (Inv. No.: HNM RR 2015.1.9), below the distinction between the wall and the foot ring, outside the base rim (Fig. 9.8). The inscription was written by not very accurately formed letters oriented radially, $\mathrm{E}=(1) \mathrm{cm} ; \mathrm{R}=1.75$ $\mathrm{cms} ; \mathrm{I}=(0.5) \mathrm{cms}$. Only a small section of the V's right bar is visible, therefore its exact height cannot be determined. The lower parts of the E, the R and the I are broken. The lower horizontal bar of the E is oblique and oriented downwards, the bowl of the $\mathrm{R}$ was formed by two straight lines meeting more or less in a right angle, thus the letter is of triangular shape. Its stem is running in a dynamic, slightly slanting, long line. The counter between the $\mathrm{E}$ and the $\mathrm{R}$ is wider than between the $\mathrm{V}$ and the $\mathrm{E}$, or between the $\mathrm{R}$ and the $\mathrm{I}$. The inscription reads:

[V]ERI.

10. Three letters were scratched on the side wall of a Drag.18/31 form plate with a SIICV[DI]M stamp (Inv. No.: HNM RR 2015.1.10). The letters are placed above the distinction between the wall and the foot ring (Fig. 10.1). The negligently scratched and oblique capital letters are of different sizes: $\mathrm{D}=0.9 \mathrm{cms} ; \mathrm{V}=0.95 \mathrm{cms} ; \mathrm{M}=1.6$ $\mathrm{cms}$. The vertical bar of the small-sized D runs higher than its bowl. The left bar of V is longer than the right one, the two bars meet in an apex; the two sidebars of the $\mathrm{M}$ are oblique, the one on the right side is higher. The inscription reads:

DVM. 
Table 1. Graffiti on the vessels of the Papkeszi terra sigillata vessel cache

\begin{tabular}{|l|l|l|l|l|}
\hline \multicolumn{1}{|c|}{ Graffiti } & $\begin{array}{c}\text { Number of } \\
\text { graffiti }\end{array}$ & \multicolumn{1}{|c|}{ Occurrence on vessel forms } & \multicolumn{1}{c|}{ Catalogue No. } & Note \\
\hline VERI & 8 & $\begin{array}{l}\text { On 4 pcs of Drag.33 and 4 pcs of Drag. } \\
18 / 31 \text { form vessels }\end{array}$ & $1-2,4,6-7,9,11-12$ & $\begin{array}{l}\text { Four-person set compiled from } \\
\text { two different form vessel types }\end{array}$ \\
\hline$D V M$ & 2 & $\begin{array}{l}\text { On 1 pc of Drag.33 and 1 pc of Drag. } \\
18 / 31 \text { form vessel }\end{array}$ & 3,10 & $\begin{array}{l}\text { One-person set compiled from } \\
\text { two different form vessel types }\end{array}$ \\
\hline$L T(?)$ & 1 & On 1 pc of Drag.33 form vessel & 8 & $\begin{array}{l}11 \text { (together with graffiti } \\
\text { Veri) }), 13\end{array}$ \\
\hline$X$ & 2 & & & \\
\hline
\end{tabular}

11. A graffiti is visible on the surface surrounded by the foot ring of the outer side of the bottom of a Drag. 18/31 form plate with a TITTIVSFE stamp (Inv. No.: HNM RR 2015.1.11) (Fig. 10.2). The not precisely scratched, radial letters are placed in a dense sequence. Their heights: $\mathrm{V}=1.7 \mathrm{cms} ; \mathrm{E}=1.2 \mathrm{cms} ; \mathrm{R}=1.7 \mathrm{cms}$; $\mathrm{I}=1.3 \mathrm{cms} ; \mathrm{X}=2.2 \mathrm{cms}$. The left bar of the $\mathrm{V}$ is cut by three strokes of different orientation and length, extending over the apex. The vertical bar of the E extends using the lower horizontal bar, which slants downwards. The lower bar was cut by using two strokes. The upper bowl of the $\mathrm{R}$ is curved and small; the I is slightly twisted. The X cut after the name is asymmetric, one of its legs is much longer than the other one, running almost until the middle of the vessel's bottom. The inscription reads:

VERIX.

12. An inscription can be found on the outer wall of the highly fragmented and incomplete Drag. $18 / 31$ form plate (Inv. No.: HNM RR 2015.1.12) with a TITTIVSFE stamp, probably an I is scartched between the foot ring and the distinction between the sidewall and the base, after the fracture. In this case, the reading of the inscription might be:

[VER]I.

13. A scratched, asymmetric $\mathrm{X}$ is visible on the sidewall of Drag. 33 form cup without a stamp (Inv. No.: HNM RR 2015.1.13), right above the horizontal line (Fig. 10.3). One of the X's bars is considerably longer than the other. Its dynamic, almost vertical line runs down between the horizontal line and the fracture. The inscription reads:

$X$

14. The middle part of the very fragmented and incomplete Drag.18/31 form plate (Inv. No.: HNM RR 2015.1.14) is broken and missing, therefore it is not known whether it had a stamp or not. There are no surviving scratched letters or letter fragments on the outer surfaces of the vessel's fragments. Possibly, the inscription was cut on the broken and lost parts of the vessel.

15. Several fragments of a larger Drag.31 form service platter (Inv. No.: HNM RR 2015.1.15), without remains of a graffiti.

\section{Vessels with graffiti VERI:}

The name Veri in the genitive case, is scratched onto eight vessels of the cache, hence their former owner was a person named Verus. The name Verus was a generally widespread, frequent Latin cognomen, thus the name itself does not allow us to draw further conclusions. ${ }^{154}$ Its gentilicium is also unkown. The name was also commonly used among the Celtic native population of the European provinces (especially in the Gaulish-Germanic provinces

${ }^{154}$ I. KAJANTO: The Latin Cognomina. Commentationes Humanarum Litterarum 36/2. Helsinki 1965, 253; ALFÖLDY 1969, 325. 
and in Noricum ${ }^{155}$ ). The name was also used frequently by natives in Dalmatia. ${ }^{156}$ However, in case of the population of Pannonian provinces before the Marcomannic-Sarmatian wars, there are hardly any examples for native bearers of the name Verus, ${ }^{157}$ the cognomen was in more common in Western Pannonia ${ }^{158}$ typically amongst foreigners of Italian, ${ }^{159}$ or perhaps western provincial origins, ${ }^{160}$ and among them, by legionary soldiers. ${ }^{161}$ This is the social background we can assume in case of the Verus of Papkeszi as well, an assumption that is supported by the owner's presumed literacy. Therefore, the general observation about writers of scratched Pannonian name inscriptions that these people were committed to the Romanitas, and typically had Latin names, is borne cut in his case as well ${ }^{162}$ Following, after the Marcomannic-Sarmatian wars the name Verus became popular also in Eastern Pannonia. ${ }^{163}$ The Drag. 32 form Rheinzabern terra sigillata bowl found in Páty-Malomdülö, also bearing the VERI proprietary graffiti on its base inside foot ring (Fig. 11) $)^{164}$ can be dated to this era. That said, the owner is not the same as of the Papkeszi cache.

The inscription VERI is present on 4 pieces of the shape of the Drag. 33 and also on 4 pieces of Drag. 18/31 form vessels in the Papkeszi cache indicating that Verus's base set was originally a four-person serving set consisting of two different form vessel types. This set was later expanded by adding further, used vessels of the same form spectrum (see below).

All the eight inscriptions with identical content were scratched by the same hand, however, although based on the placement of the inscriptions and slightly differently formed letters, probably not in the same time. The handwriting and shape of the capital letters can be well characterized as follows (Fig. 12).

A general observation is that letters - despite their inaccurate execution - are well legible.

$\mathrm{V}$ : The letter $\mathrm{V}$ is present on 5 vessels. In three cases, bars of $\mathrm{V}$ do not meet in an apex, and they cross each other in two cases. In three cases, the left bar of $\mathrm{V}$ was cut by two or three strokes (11).

$\mathrm{E}$ : The letter $\mathrm{E}$ is present on 7 vessels. The vertical bar of $\mathrm{E}$ consistently extends over the lower horizontal bar, which is typically shorter than the other horizontal bars. The horizontal bars of $\mathrm{E}$ are slanting downwards in four cases, while in three cases they are orthogonal to the vertical crossbar of the letter $(2,6-7)$. The vertical crossbar is cut by a single, firm line in all cases, while in the case of vertical bars, they are cut by two strokes in two cases.

$\mathrm{R}$ : The letter $\mathrm{R}$ has remained in four complete and three fragmented versions. The writer of the inscription applied two different methods to create the upper bowl of the capital R-s. On vessels where the upper part of the letter has remained, the bowl is either arched $(2,7,11)$ or squarely formed, because of the rigid surface of the material $(4,9)$. The vertical crossbar of the letter was cut by more lines in two cases $(1,2)$.

I: The letter I has remained intact as all of the eight vessels with inscription VERI. It is written by a firmly cut vertical line. I has a slightly twisted shape only in two occasion $(4,11)$.

The name Verus was scratched on different parts of the vessels by the person who made the inscriptions, even if the vessels were of identical forms.

1. In two cases, on the base inside foot ring $(1,11)$,

2 . in three cases, on the side wall of the vessel $(2,6-7)$,

3 . in three cases, on the surface between the distinction and foot ring $(4,9,12)$.

${ }^{155}$ B. LŐRINCZ: Onomasticon Provinciarum Europae Latinarum. IV: Quadratia - Zures. Ex materia ab András Mócsy, Reinhardo Feldman, Elisabetha Marton et Mária Szilágyi collecta. Wien 2002, 160-161, with statistic of the occurrences of 'Verus' cognomen in the European provinces. On the existence of the name in the Gallic provinces: A. MócsY: Bemerkungen zu den negotiatores von Colijnsplaat. MBAH 3.2 (1984) 47, Fig. 3.

${ }^{156}$ ALFÖLDY 1969, 325.

${ }^{157}$ M. Ulpius M. f. Verus dec. m(unicipii) A(elii) K(arn.), IIII i. d.: CIL III 4554 (Mutmannsdorf) - cf. MócsY 1959, 226 122/1.

${ }^{158}$ BARKÓCZI 1964, 327.

${ }^{159}$ E. g. P. Rufrius Verus (from Northern Italy, presumably from Aquileia): CIL III 3896 (Vernek/Warnegg) - cf. MócsY 1959, $208,26 / 1 ;$ Q Annaeus Verus (also a descendant of a family from Aquileia): CIL III 3928 (Senuše) - cf. Mócsy 1959, 209, 39/1; L. Valerius Verus (italicus): AIJ 288 (Poetovio) - cf. Mócsy 1959, 215, /4/55; Salvia M. $f$. Vera (from Northern Italy): CIL III 4210 (Szentpéterfa) - cf. Mócsy 1959, 218, 85/1; Iulia Vera (Northern
Italian): CIL III 13426 (Rotenturm) - cf. MócsY 1959, 222, 94/2; Sextilia Vera (from a Northern Italian family): AE 1912, 8 = AE 1913, 57 (Scarbantia) . cf. Mócsy 1959, 225, 111/20.

${ }^{160}$ T. Flavius Verus (offspring of a veteranus legionis from Agrippinensis): CIL III 3642 = RIU (Szentendre) - cf. MócsY 1959, $247,176 / 2$.

${ }^{161}$ C. Cornelius C.f. Pom. Dert(ona) Verus, vet. leg. II Adi. (italicus): CIL III 4057 (Poetovio) - cf. MócsY 1959, 213, 64/3; C. Statius Verus centurio leg. XIII: CIL 4246 (Schattendorf) - cf. MócsY 1959, 225, 113/1; Flavius Verus: CIL III 4470 (Carnuntum) - cf. Mócsy 1959, 240, 155/16; L. Carisius L. f. Pomptina Verus Aretio arm. [custodi l]eg. [ - - : CIL III 14349 $=$ TitAq 954 (Aquincum) - cf. MóCSY 1959, 251, 185/35.

${ }^{162}$ BARTA 2006, 127

${ }^{163}$ BARKÓCZI 1964, 327

${ }^{164}$ D. GABLER: Terra sigillatak a pátyi telepen - Terra Sigillaten in der römischen Siedlung Páty-Malom-Flur. StComit 30 (2007) 245, Kat. 87, Fig. 8. 


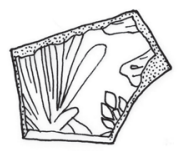

1

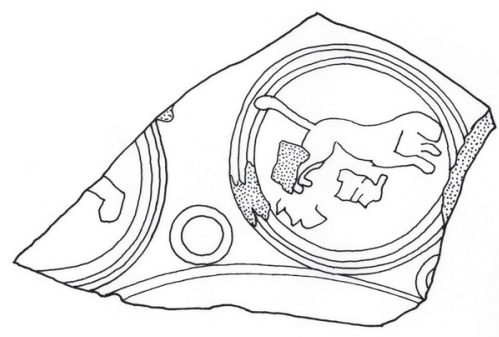

3
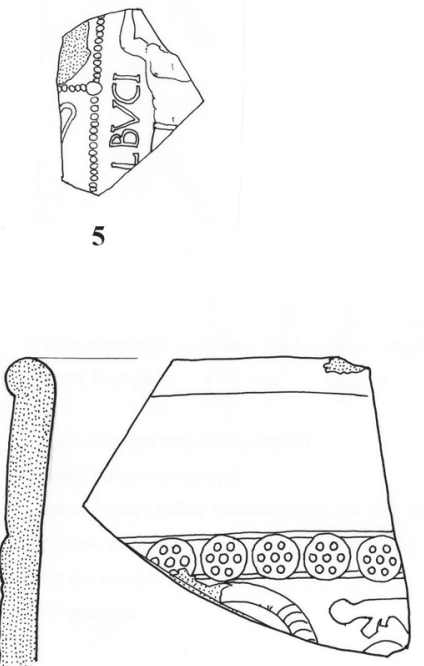

7
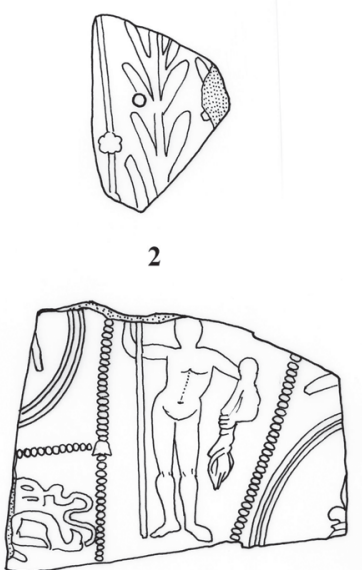

4

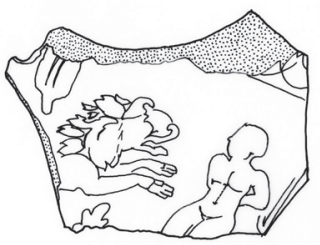

6

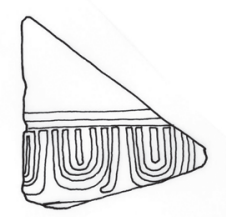

8

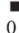

Fig. 11. Samian ware from the Roman settlement at Papkeszi

As a general feature of inscriptions of vessels that were designed for table use, while the vessels were used the inscriptions were not, or were barely visible: this is true for all the three above placements of inscriptions. ${ }^{165}$

The letters of the inscriptions are consequently radially oriented in the first two positions. They were written on the surface of the vessels on different spots and by diversely scratched letters, indicating that most probably the acquisition of vessels had happened in different time periods, in more instalments and instances. It can be assumed that the final assortment of the eight-piece set was a result of at least three acquisition phases. This theory is supported by the shape of the scratched letters, as inscriptions scratched to analogous spots show close similarity with each other. For instance, the angular bowl of R is present only at graffiti scratched to the surface between the

165 TH. ECKINGER: Die Töpferstempel der Sammlung Antiquarischen Gesellschaft von Brugg und Umgebung. ASA N.F. 4 (1902-1903) 272; BAKKER-GALSTERER-KRÖLL 1975，55-56;
B. GALSTERER: Die Graffiti auf der römischen Gefäßkeramik aus Haltern. Bodenaltertümer Wetfalens 20. Münster 1983, 6; BARTA 2006 124. 


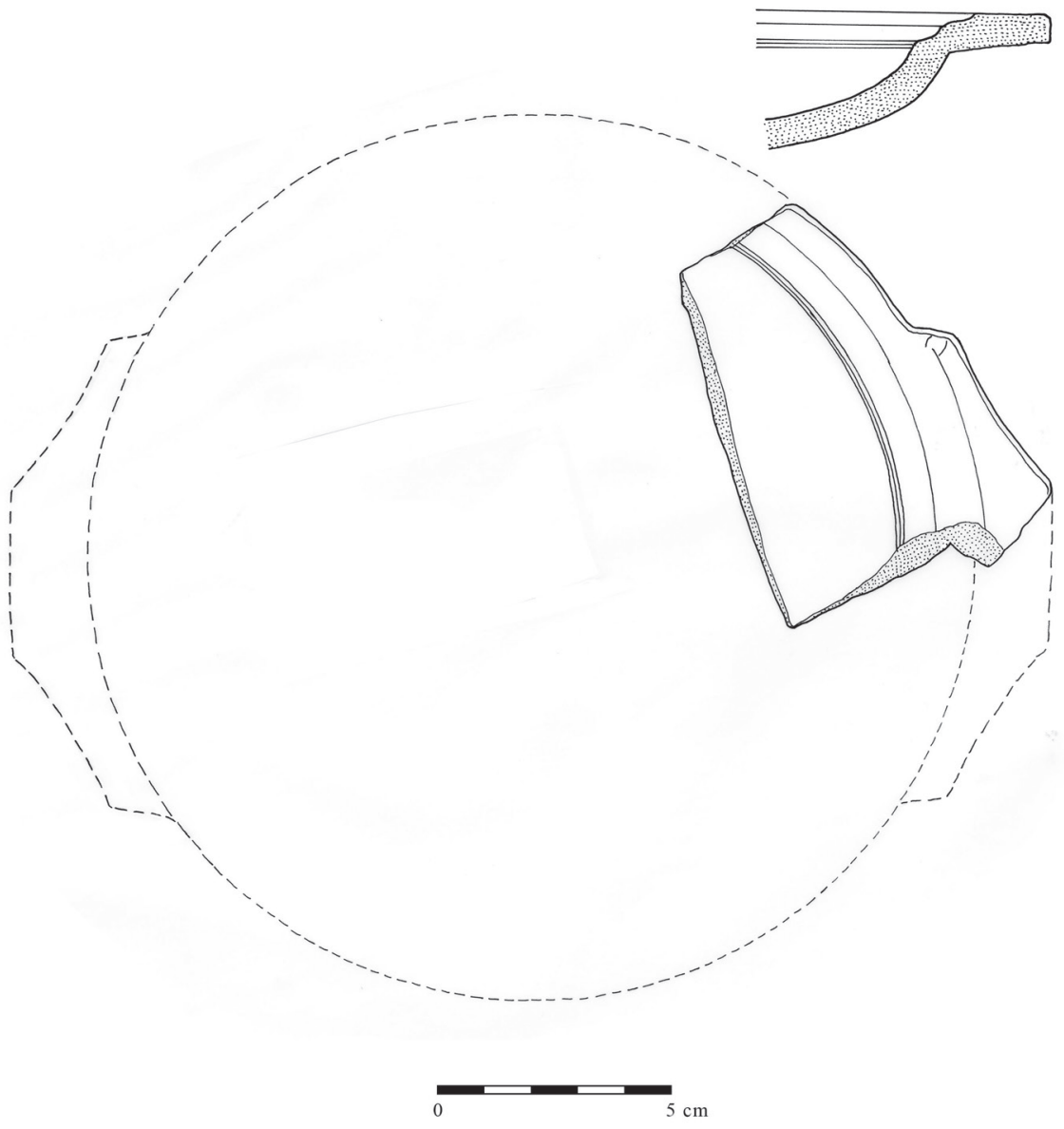

Fig. 12. Lanx Drag.39 from the Roman settlement at Papkeszi

distinction and the foot ring $(4,9)$, while in other cases, the bowl has an arched shape. The horizontal bars of the E on sidewalls are always perpendicular to the vertical crossbow, while in other cases, they are oblique. The sequence of letters of the graffiti between the distinction and the foot ring is always less dense, the counter is always bigger than in other cases.

The accessibility of the chosen place of the inscriptions also influenced how precisely the letter was scratched. For instance, scratching an inscription into the base surrounded by the foot ring (see No. 11) was much more complicated, because inside the footring of the vessel presents a narrower surface to write on than the sidewall.

\section{Vessels with inscription DVM}

It is uncertain whether the three letters are an abbreviation of a Roman citizen's tria nomina or his/her most probably Celtic Dum(- - -) cognomen ${ }^{166}$ or prefer they should be interpreted differently (for instance, as numerals). A very similar letter sequence was found on the Northern Italian terra sigillata vessels of grave No. 4 of the cemetery at Nemesböd (Vas county): on these vessels, letters MDI are scratched.

The shape of the letters and of the handwriting is considerably different on the two vessels with inscriptions DVM $(3,10)$. This suggests either two different hands or a chronological difference of their scratching. Based on the significant similarity of the $\mathrm{V}$-s, the latter scenario seems more probable. The graffiti on vessel 10 is written by

${ }^{166}$ LÖRINCZ 1999, 111. 

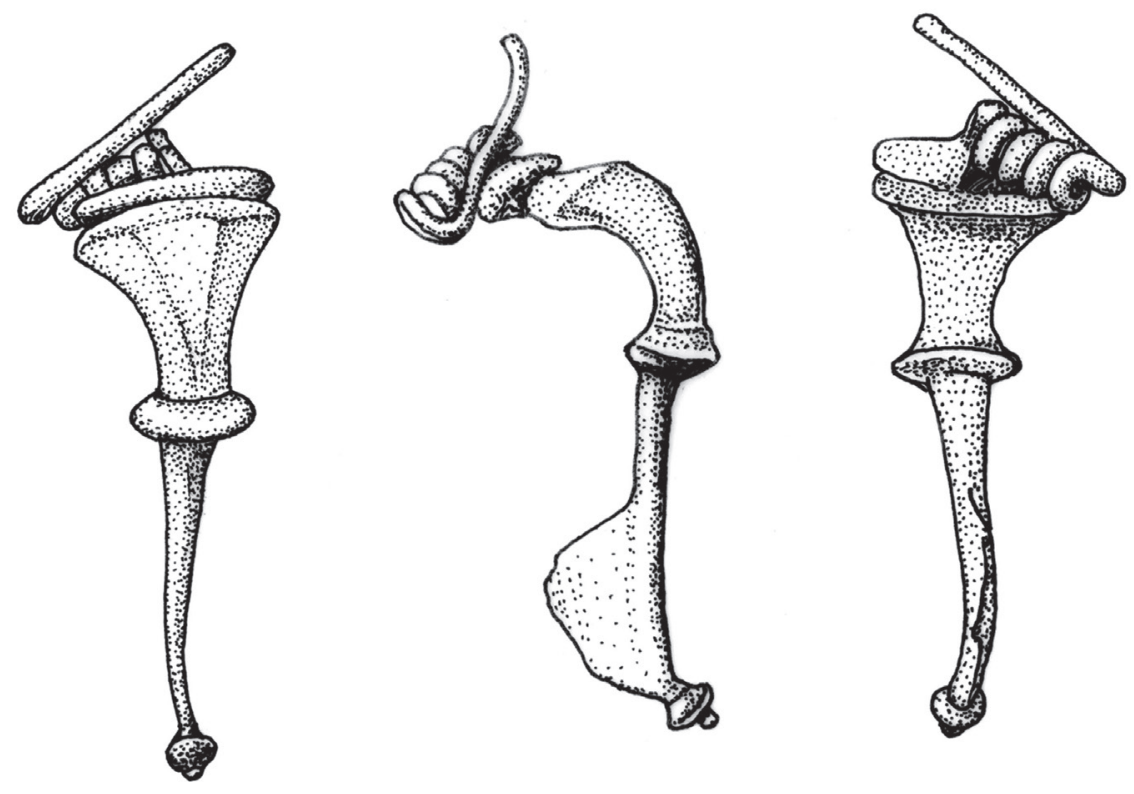

1
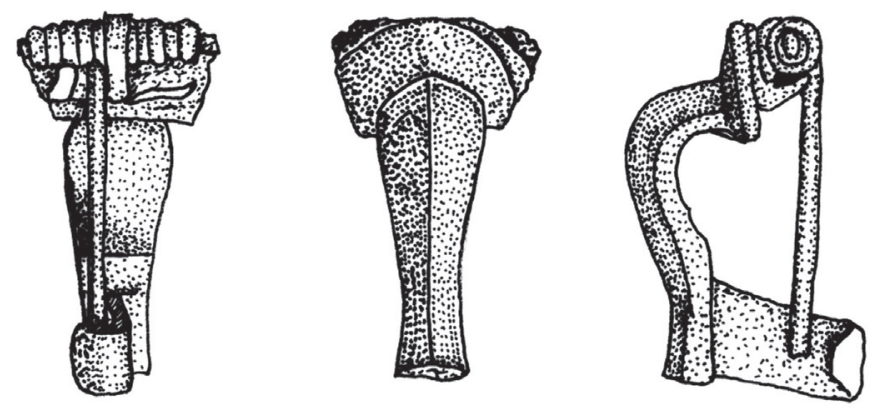

2

0 $3 \mathrm{~cm}$

Fig. 13. Brooches from the Roman settlement at Papkeszi

letters of different heights, which follow each other in a dense sequence and are slanting to the left. Contrastingly, on vessel 3 letters are almost of the same height, and their sequence is more scattered and aligned. The analysis of the individual letters is as follows:

D: On vessel 10, D has a small bowl, a vertical bar and a crossbar extending over the upper part, while on vessel 3, D is somewhat triangular.

$\mathrm{V}$ : The two stems of the $\mathrm{V}$ meet in an apex, the bar on the left side is cut longer than the right one in both cases.

$\mathrm{M}$ : The two outer bars of $\mathrm{M}$ stand in a straddle. On vessel $10 \mathrm{M}$ is narrower and higher, while on vessel 3 it is wider and shorter. 


\section{Vessel with LT graffiti}

Although the strokes of the two letters of graffiti LT - present only on one vessel (8) - cross each other, this cannot be considered a ligature: because their application of ligatures on scratched inscriptions is particularly rare. ${ }^{167}$

\section{Vessels marked with an $X$}

$\mathrm{X}$ appears inside the base rim of vessel 11, connected to the graffiti Veri, probably cut at the same time as the inscription itself. Perhaps Verus marked his own vessel within the set.

In connection with mark $\mathrm{X}$ below the rim of vessel 13 - if the mark was indeed made intentionally - we face the same interpretation problems as in the cases of other single $\mathrm{X}$ incisions. ${ }^{168}$ It cannot be decided whether the letter marks a number, quantity, or perhaps ownership or a specific user.

\section{Vessels without inscriptions $(5,14-15)$}

No inscription or other scratched mark was detected on three vessels and on one serving platter, but this can be explained by the very fragmented and incomplete state of the vessels, because inscriptions could have been placed on the missing fragments of vessels.

The presence of vessels with the two DVM and one LT inscriptions within the set indicates that the last owner of the set bought the vessels or got them as a present in different times. The $2+1$ vessels with different ownership marks probably became part of the set of Verus as gifts or by inheritance. It should be noted that the graffiti DVM appears on a Drag.33 form cup and a Drag.18/31 form bowl probably comprising part of the same (earlier?) owner's personal set, which was assembled from single pieces of different forms.

In the case of sets from a closed context (grave, cache or rubbish pit) consisting of vessels marked with possessor's names or other signs it may occur that all pieces of the cache, or at least the majority of them, are marked by names/possessor marks of the same person. An example might be the MDI letter group or its variants, interpreted as tria nomina, which were scratched onto 6 vessels (five of them are terra sigillata plates) found in grave No. 4 excavated in the Roman cemetery at Nemesböd. ${ }^{169}$ (One of the Northern Italian terra sigillata bowls from the same grave, however, has a different name on it.) 25 peices of grey vessel fragments with the inscription of female name Paulina were found at Nagykanizsa in a rubbish pit, at the Inkey chapel Roman settlement. ${ }^{170}$ They are likely part of a full set owned by the same person. However, pieces of a set are not necessarily marked by names of the same person. In the vessel cache from Tác, which is contemporary with the Papkeszi one, all the vessels have different possessor's names or marks on them. ${ }^{171}$ It can be hardly decided whether what was the motive of the property marks and names. Prevent form the theft is only one possibility among the other reasons. ${ }^{172}$

The presence of written communication can be demonstrated within the population of rural settlements of the Pannonian provinces (villas and villages situated further from towns and forts as well as fortresses): as mainly evidenced by graffiti (Table 2). In Southern Britannia $8 \%$ of all known graffiti originate from villas a further $7 \%$ are from other types of rural settlements, ${ }^{173}$ and this ratio can be confirmed by data ${ }^{174}$ from other territories (e.g. Raetia ${ }^{175}$ )

${ }^{167}$ BAKKER-GALSTERER-KRÖLL 1975, 29.

${ }^{168}$ Zs. VisY: Inscriften und Zeichen auf den Terra Sigillaten von Intercisa. Alba Regia 10 (1969) 91-92; BAKKER-GALSTERERKRÖLL 1975, 51; BARTA 2006, 125-127.

${ }^{169}$ BARTA 2015, 67-68.

${ }^{170}$ BILKEI 1985, 6-7.

${ }^{171}$ Gabler-KoczTUR 1977, 88, Taf. VII.

${ }^{172}$ For the graffiti connected with theft, see comprehensively: M. REUTER: Kriminalität und Kleininschriften. Ein noch unerschlossenes Forschungsfeld. In: Lesen und Schreiben in den römischen Provinzen. Schriftliche Kommunikation im Alltagsleben. Akten des 2. Internationalen Kolloquiums von DUCTUS. RGZM Mainz, 15-17. Juni 2011. Hrsg.: M. Scholz, M. Horster. RGZM-Tagungen 26. Mainz 2015, 107-112.

${ }^{173}$ W. S. Hanson-R. CONOLlY: Language and literacy in Roman Britain: some archaeological considerations. In: Becoming Roman, Writing Latin? Literacy and epigraphy in the Roman West. Ed.: A. E. Cooley. JRA Suppl. 48. Portsmouth 2002, 153.

${ }^{174}$ SCHOLZ 2015, 69. 
as well. Although we do not have a similar calculation for the Pannonian provinces yet ${ }^{176}$ but the fact that currently more than 300 graffiti consisting surely of letters and/or numerals were collected in Aquincum, ${ }^{177}$ and more than 170 graffiti were collected at the municipality of Salla (Zalalövő), we can presume a similar ratio. ${ }^{178}$ The relatively small number of graffiti from rural settlements in comparison with Roman centres can be explained by the fact that rural communities were smaller and more embraceable, thus marking personal belongings was less needed. ${ }^{179}$

Most of the inscriptions from the explored territories were found in villas, especially in their pars urbana parts (such as Nemesvámos-Balácapuszta), or in vici functioning as important pagus centres (such as Tác-Fövenypuszta [Gorsium?]), but a significant number of graffiti were found also at settlements and cemeteries where italici were settled (Alsópáhok, Magyarszerdahely, Nemesbőd). At certain sites the number of unearthed graffiti is evidently in correlation with the intensity of archaeological research at the given site.

The vast majority of names of the graffiti listed in the table - similarly to the Papkeszi inscriptions - refer to Latin names, ${ }^{180}$ most frequently the nominative case. Exceptions are the two native names scratched on late LaTène pottery forms found in the vicus of Páty-Malomdülö (COIMO and VIDNORIX [=Vindorix?]). The language and the font set of the inscriptions is usually also Latin, apart from a few Greek exceptions. ${ }^{181}$

In a rural environment graffiti are present not only on more expensive, imported or decorative pottery (such as on terra sigillata vessels) but often on household pottery as well. For instance, the medium of inscriptions of the 65 graffiti found at the Nagykanizsa, Inkey chapel site is gray household pottery in all cases.

In summary, based on the inscriptions, the following conclusions can be drawn about the Papkeszi vessels and the cache itself:

1. The association of vessels as part of the same set is evidenced by the VERI graffiti present on 8 vessels. This refers to the same person in the genitive case.

2. In the case of the 8-piece Verus set the three different placements and the slightly divergent line tracing of the inscriptions' letters indicates that vessels of the set were obtained over course of at least three acquisition phases by their owner and the set was probably further extended by, additional used vessels (vessels with DVM, LT and X graffiti).

3. The graffiti attributed to rural inhabitants illustrate well the spread of literacy in the countryside situated further from Roman centres (towns, auxiliary forts and legionary fortresses) in the case of Pannonian provinces as well (Fig. 13).

\section{OTHER FINDS FROM THE SITE OF THE DEPOT}

Besides the stamped platters and cups, more samian vessels were taken to the Hungarian National Museum from the site. Among these - from the perspective of the sequence of the site - the following ones attract more attention:

1. Wall fragment of a Drag. 37 bowl, with a fragment of a bush consisting of four-lobed leaves (Knorr 1919, Textb. 12), a section of a flower garland (Jacobs 1912, Taf. I.4-5) and the head of a dog(?) running to the left (O. 1994?) (Fig. 11.1)

Ware from La Graufesenque, workshop of Mercator or Mascuus

Domitianic-Trajanic period

2. The base of a Drag.37 bowl, with a garland consisting of triplets of leaves (Knorr 1919, Taf. 57,12 F-G; Jacobs 1912, Taf. I.3-4; Juhász 1935, Taf. II.14) (Fig. 11.2)

Ware from La Graufesenque, workshop of Mercator or Mascuus

Domitianic-Trajanic period

3. Wall fragment of a Drag. 37 bowl with metope and zone devided by beads. On the right stamp ALBVCI (names I6h) (Fig. 6.5)

Ware form Lezoux, workshop of Albucius

AD 145-180.

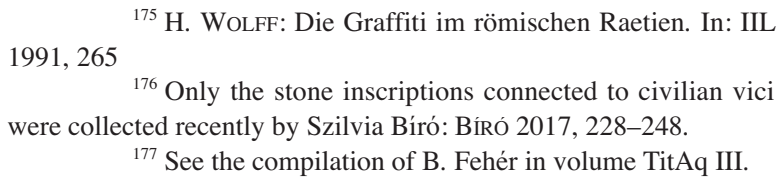

${ }^{175}$ H. WoLfF: Die Graffiti im römischen Raetien. In: IIL 1991, 265

${ }^{176}$ Only the stone inscriptions connected to civilian vici were collected recently by Szilvia Bíró: BíRó 2017, 228-248.

${ }^{177}$ See the compilation of B. Fehér in volume TitAq III.

${ }^{178}$ BARTA 2006

${ }^{179}$ SCHOLZ 2015, 70.

${ }^{180}$ BiLKeI 1985, 11; BARTA 2006, 127.

${ }^{181}$ BILKEI 1985, 7, Kat. 26; 8, Kat. 32 (Nagykanizsa, Inkey chapel). 
Table 2. Graffiti from rural settlements in Pannonian provinces in the territory of Hungary (incomplete list)

\begin{tabular}{|c|c|c|c|}
\hline Site & Context & $\begin{array}{l}\text { No. of } \\
\text { graffiti }\end{array}$ & Reference \\
\hline $\begin{array}{l}\text { Alsópáhok } \\
\text { (Zala county) }\end{array}$ & $\begin{array}{l}\text { grave No } 5 \text {. in the cemetery of a rural } \\
\text { settlement }\end{array}$ & 1 & HoRVÁth-TOKAI 2012, 199, Fig. 11.1 \\
\hline $\begin{array}{l}\text { Bakonyszentlászló } \\
\text { (Veszprém county) }\end{array}$ & rural settlement & 2 & $\begin{array}{l}\text { CSIRKE-GABLER-PALÁGYI 2006, } 28 \text { Kat. } 2.5 \\
\text { and 30, Kat. } 2.18\end{array}$ \\
\hline Balatonfüzfö (Veszprém county) & rural settlement and pottery workshop & 1 & MRT 2, 47, Fig. 7 \\
\hline Budaörs (Pest county) & vicus and central settlement of a pagus & 2 & MRÁv 2014, 109-110 \\
\hline Cserdi (Baranya county) & villa & 1 & SzABÓ et al. 2014, 260, 274. \\
\hline $\begin{array}{l}\text { Letenye, Main square } \\
\text { (Zala county) }\end{array}$ & countryside settlement & 1 & BILKEI 1985, 10 Kat. 74. \\
\hline $\begin{array}{l}\text { Magyarszerdahely } \\
\text { (Zala county) }\end{array}$ & $\begin{array}{l}\text { from three graves of a rural settlement's } \\
\text { cemetery }\end{array}$ & 7 & $\begin{array}{l}\text { HORVÁTH 1979; BILKEI 1985, 10, Kat. 66- } \\
\text { 73; IIL } 1991\end{array}$ \\
\hline $\begin{array}{l}\text { Nagyharsány, Kopár and } \\
\text { Kopáralja ridges } \\
\text { (Baranya county) }\end{array}$ & rural settlement, later a villa & 2 & Unpublished \\
\hline $\begin{array}{l}\text { Nagykanizsa, Inkey chapel } \\
\text { (Zala county) }\end{array}$ & rural settlement & 65 & $\begin{array}{l}\text { BILKEI 1985, 6-10, Kat. 1-65; IIL 1991, } \\
\text { 142-143 }\end{array}$ \\
\hline $\begin{array}{l}\text { Nemesböd } \\
\text { (Vas county) }\end{array}$ & $\begin{array}{l}\text { grave No } 4 \text {. of the cemetery of a a rural } \\
\text { settlement }\end{array}$ & 6 & BARTA 2015 \\
\hline $\begin{array}{l}\text { Nemesböd, Írtásdülő } \\
\text { (Vas county) }\end{array}$ & $\begin{array}{l}\text { rural settlement (probably farm buildings } \\
\text { of a villa) }\end{array}$ & 1 & SIMON 2014, 328, 330, Fig. 2.7 \\
\hline $\begin{array}{l}\text { Nemesvámos, Balácapuszta } \\
\text { (Veszprém county) }\end{array}$ & villa settlement & 34 & FEHÉR-KOVÁCS 2001 \\
\hline $\begin{array}{l}\text { Papkeszi } \\
\text { (Veszprém county) }\end{array}$ & $\begin{array}{l}\text { terra sigillata depot find from a rural set- } \\
\text { tlement }\end{array}$ & 12 & Published here \\
\hline $\begin{array}{l}\text { Páty-Malom ridge } \\
\text { (Pest county) }\end{array}$ & vicus & 8 & $\begin{array}{l}\text { GABLER-OTtOMÁNYI 1985, Taf. XX.13, Taf. } \\
\text { XXI.4, Taf. XXIV.1-4; Gabler 2007, 245, } \\
\text { Kat. 87, Fig. 8, 246, Kat. } 98 .\end{array}$ \\
\hline $\begin{array}{l}\text { Pécs-Vasas } \\
\text { (Baranya county) }\end{array}$ & cemetery of a rural settlement & 2 & $\begin{array}{l}\text { FÜLEP 1958, 376, Abb. 3.2.6, 382, Abb. } 5 . \\
5.9 .\end{array}$ \\
\hline $\begin{array}{l}\text { Ravazd, Simahegy } \\
\text { (Györ-Moson-Sopron county) }\end{array}$ & rural settlement & 1 & Bíró 2007, 32, Fig. 4.4 \\
\hline Ságvár-Végh mill (Vas county) & mansio & 2 & GABLER 1998, 250, Nr. 57, 251, Nr. 64 \\
\hline $\begin{array}{l}\text { Solymár-Dinnyehegy } \\
\text { (Pest county) }\end{array}$ & cemetery of a native settlement & 2 & $\begin{array}{l}\text { IIL 1991, 128, Kat. Nr. 177a-b; A. Mócsy } \\
\text { in: KoczTuR 1991, 211-212. }\end{array}$ \\
\hline $\begin{array}{l}\text { Somos II } \\
\text { (Veszprém county) }\end{array}$ & rural settlement & 1 & $\begin{array}{l}\text { CSIRKE-GABLER-PALÁGYI 2006, 203, Kat. } \\
42.3 .2\end{array}$ \\
\hline Söjtör (Zala county) & tumulus & 2 & BILKEI 1985, 10, Kat. 75-76 \\
\hline Szekszárd (Tolna county) & rural settlement & 1 & IIL 1991, 125, Nr. 178. \\
\hline $\begin{array}{l}\text { Tác-Fövenypuszta } \\
\text { (Fejér county) (Gorsium?) }\end{array}$ & $\begin{array}{l}\text { vicus and probably the central settlement } \\
\text { of a pagus }\end{array}$ & $\begin{array}{l}36+14 \\
\text { (from depot } \\
\text { find) }\end{array}$ & $\begin{array}{l}\text { See reports Forschungen in Gorsium in the } \\
\text { volumes of Alba Regia. On the cache: } \\
\text { GABLER-KocZTUR 1976, 88, Taf. VII }\end{array}$ \\
\hline $\begin{array}{l}\text { Tokod-Erzsébetakna } \\
\text { (Komárom-Esztergom county) }\end{array}$ & rural settlement & 7 & IIL 1991, Kat. 136-138, Kat. 204-210. \\
\hline
\end{tabular}

4. The base of a Drag. 37 bowl, with a lioness (O.1510) between double circles (Karnitsch 1959, Taf. 48,1). There is a smaller circle between the larger medallions (Karnitsch 1959, Taf. 45,2). (Fig. 11.3)

Ware from Lezoux, workshop of Paternus (style II) or Censorinus

AD 180-190

5. Greater part of a Drag. 37 bowl, with a metope and zone division by beads. (Fig. 11.4) In the upper metope, a double semicircle (CGP fig. 159,24) with an astragalus (CGP fig. 47,40), in the lower section, a hippocampus (O. 2391; CGP fig. 164,3). The long-shaped metope on the right side has a hero with a lance (O. 143; Karnitsch 1959, Taf. 65,4). On the right, in a wider zone, a double circle (CGP fig. 160,35). Similar decoration: CGP fig. 158,22

All the motifs are present in the repertoire of Cinnamus. 
Ware from Lezoux, workshop of Cinnamus.

AD $140-180$

6. Wall sherd of a Drag.37 form bowl. (Fig. 11.6) Only a small fragment of the ovolo is visible (Ri-Fi E 55 ?). In the image zone, a tied figure (Ri-Fi M 231a) is attacked by a lion (Ri-Fi T 15). On the left, an ornament similar to another ovolo (Ri-Fi O. 112 ?).

Ware from Rheinzabern, Reginus I series.

From the period of Antoninus Pius-Marcus Aurelius

7. Rim fragment of a Drag. 37 form bowl. The ovolo is substituted by a rosette, formed by 6 points pressed to create a disc (Ri-Fi R 13). In the image zone, there is a blurred arc and a stylized bird. See LuD VI, Taf. 146,2. (Fig. 11.7).

Ware from Rheinzabern, Augustinus I and III series.

8. Wall sherd of a Drag.37 form bowl, with an ovolo (Gabler-Kellner E 10). (Fig. 11.8)

Ware from Westerndorf, Helenius.

Severan period, middle of the $3^{\text {rd }} \mathrm{c}$.

9. Wall and rim fragment of a Drag. 39 form lanx. On the inner side of the rim, the handle is divided by a deep groove (see Düerkop-Eschbaumer 2007, Taf. 49, 19,Fl. 2, 49) (Fig. 12).

Ware from Rheinzabern

Late Antonine - early Severan period

It is a question whether of the two earliest vessel fragments (1-2) can be attributed to Mercator, or to Masculus. Mercator only gave his name on Drag. 37 bowls, indicating that he did not produce Drag. 29 form, a form already rare by that time. Correspondingly, the beginning of his production can be dated to around 85 . Mercator is one of the most productive potters, which can be attributed to the fact that he often stamped his ware. The early phase of his activity was possible to define on the basis of data from firmly dated sites: his products were found at Heilbronn-Böckingen, Saalburg and Ladenburg in layers that were dated by coins of Trajan. At Ladenburg, the coin minted in 101 indicates that the officina was still in operation around 100. Based on stylistic elements, the emphasis in his activities fell rather in the $90 \mathrm{~s}^{182}$ His ware often emerge in Noricum and Pannonia. At Vindobona, a total of 37 of his vessels were found at 11 sites. His relief-decorated ware is present at Carnuntum, Gerulata, Arrabona, Brigetio, Tokod, Budaörs, Aquincum, Albertfalva, Gorsium, Baláca, Sárvár and Salla. ${ }^{183}$

The vessels of Masculus can be found also in the fill of the great kiln at La Graufesenque, where they were discovered together with the bowls of L. Cosius and Germanus IV ${ }^{184}$ Based on the material in the great kiln and the presence of Masculus's vessel at Cannstatt, his activity can be dated to the years between $80-120 .{ }^{185}$ His wares are frequently present in the Danubian provinces. In Pannonia, his wares have so far been found at Vindobona, Carnuntum, Gerulata, Brigetio, Aquincum, on the sites of Budaörs, Albertfalva, Savaria and Salla. ${ }^{186}$

Paternus V (Nr. 3) was active at Lezoux, but he could also have owned a workshop at Les Martres-de-Veyre and Vichy. According to the previous opinion of B. Hartley, his production might have begun around $160^{187}$ and lasted at least until 180 or $190 .{ }^{188}$ However, Hartley and Dickinson's more recent dating has been given as AD 150-185. His products are often present in the material from destruction layers related to the Marcomannic wars, ${ }^{189}$ such as in the cases of Salla, Arrabona, Aquincum and Mursa, ${ }^{190}$ His decorated bowls were found at Carnuntum in the legionary fortress, in the auxiliary castellum, and in the Steilhang excavation and Pfaffenberg finds. ${ }^{191}$

The assemblage that was handed over to the Museum also contains the vessel of Cinnamus catalogued here (4). Products of this officina reached almost every corner of Pannonia and the Danubian provinces in general. It

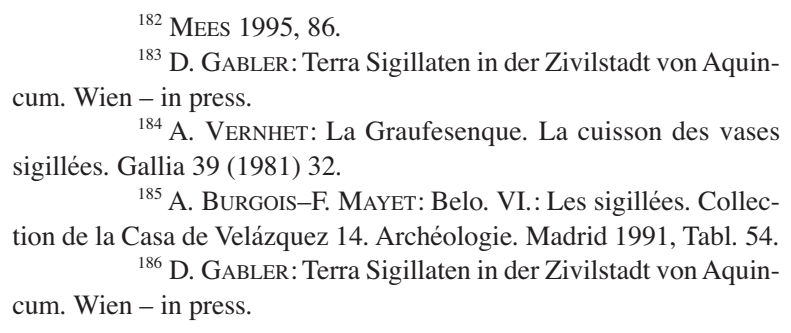

${ }^{183}$ D. GABLER: Terra Sigillaten in der Zivilstadt von Aquincum. Wien - in press.

${ }^{184}$ A. VERnhet: La Graufesenque. La cuisson des vases sigillées. Gallia 39 (1981) 32.

${ }^{185}$ A. BURGOIS-F. MAYET: Belo. VI.: Les sigillées. Collection de la Casa de Velázquez 14. Archéologie. Madrid 1991, Tabl. 54. cum. Wien - in press.

${ }^{187}$ HARTLEY 1972, 33

${ }^{188}$ ROGERS 1999, 190

${ }^{189}$ FABER 1994, 184.

${ }^{190}$ GABLER 1994, 306

${ }^{191}$ D. GABLER: Sigillaten in Carnuntum und auf dem Pfaffenberg. In: Anodos. Studies of the ancient world 8 (2008) in honour of Werner Jobst. Trnava 2010, 186. 
would be an impossible challenge to provide a list with detailed data from all the sites, as those vessels which can probably be attributed to this workshop and which have been published so far include 170 vessels from Vindobona alone and 90 vessels from Carnuntum. ${ }^{192}$ Also, 93 of his products are recorded in Aquincum. It is probable that Cinnamus managed the biggest officina at Lezoux; however, this officinator may have supplied more Central Gaulish production centres with moulds (Lubié, Toulon-sur Allier, Vichy, Terre France). His products are rarely present at forts on Hadrian's Wall; therefore the main period of his production may be dated after $160 .{ }^{193}$ Within the productionphases of the workshop, G. Simpson and G. Rogers differentiated an early period between 135-145, the so-called partnership period with Cerialis (II) ${ }^{194}$ His production at Lezoux probably ended around 175, when because of the Marcomannic wars opportunities for exportation were hindered in the direction of the Danubian provinces, one of its greatest markets. At Lubié or Vichy, he could have continued production for a while longer. It is not a coincidence that Cinnamus's ware are one of the dominant types in destruction layers that are related to the Marcomannic wars.

Among the samian ware from Rheinzabern, the earliest is the piece that can be connected to the Reginus I series (5). This workshop used its own set of stamps; that is, it was less likely to take over elements of decoration from other officinae. Therefore, the identification of Reginus I ware is easier than in the case of other potters. H. Bernhard classified this series as one of the earliest ones, ${ }^{195}$ but this is contradicted by the Yule formula used by A. Mees. ${ }^{196}$ On the basis of the large number of products connected to the workshop, we may rightly come to the conclusion that more than one potter was working in this officina. Its production can be dated to the third quarter of the $2^{\text {nd }}$ century; its products might have been on the market until around 180. In Pannonia, we may attribute more than 60 bowls to this workshop so far. Most of its products were found at Vindobona ${ }^{197}$ and Carnuntum, but a relatively large quantity was found in the fort of Ács-Vaspuszta in destruction layers related to the Marcomannic wars. ${ }^{198}$ In the inner parts of the province these types are relatively rare: one item is recorded from Sárvár ${ }^{199}$ and one from Baláca. ${ }^{200}$ On one of the bowls the ovolo is substituted by a frieze formed by pointed-line rosettes. This item can be classified in the Augustinus I, III series (6). H. Ricken, who also studied the products of the manufacture of Rheinzabern, claims that Augustinus's production form a greater block. These ideas were only partially accepted by A. Mees: he claims that the Augustinus III series can be divided even further ${ }^{201}$ Dating the workshop is a difficult task, as its products were not so widespread; firmly datable assemblages cannot therefore provide an aid in defining the sequence of their production. Based on the evidence of the basement finds at Sulz, the series might have been on the market at the end of the $2^{\text {nd }}$ century; however, it can be stated for sure that the Augustinus group did not belong to the early Rheinzabern potters. The group's products are also rare in Pannonia: they are present at Vindobona, Carnuntum, Strebersdorf, Brigetio, Celamantia, Budaörs and Aquincum. ${ }^{202}$

The latest piece among the terra sigillata finds from the Papkeszi is a fragment produced at Westerndorf (7). Although only an ovolo remains, this item can be identified distinctly as a product of Helenius's workshop. Production of samian might have begun around 175 at Westerndorf, ${ }^{203}$ but the officina of Helenius probably begun its operation around 200. ${ }^{204}$ Helenius also produced relief-decorated bowls at Rheinzabern; his Rheinzabern production were found in the cemetery of Regensburg (dated to after 179), at Holzhausen (built after 185) or in the assemblages from the $3^{\text {rd }}$ phase of Heddernheim, thus it can be supposed that Helenius's workshop at Rheinzabern was active after $180 .{ }^{205}$ The active period of the officinator's Rheinzabern and Westerndorf workshops did not necessarily coincide. ${ }^{206}$ Previously, it had been supposed that Westerndorf was destroyed in the first Alemannic raid

192 Ibidem.

${ }^{193}$ Names 3, 26

${ }^{194}$ G. Simpson-G. Rogers: Cinnamus de Lezoux et quelques potiers contemporaines. Gallia 27 (1969) $3 \mathrm{ff}$.

${ }^{195}$ H. Bernhard: Zur Diskussion um die Chronologie Rheinzaberner Relieftöpfer. Germania 59 (1981) 84.

${ }^{196}$ MEEs 2002, 325.

${ }^{197}$ WeBER-Hiden 1996, Taf. 83, 1-8, Taf. 84, 1-5; Taf. 85, 1-10; DONAT 1999, 213.

${ }^{198}$ D. GABLER: The Roman Fort at Ács-Vaspuszta on the Danubian Limes. BAR IntSer 531. Oxford 1989, 456-457.

${ }^{199}$ F. HORVÁTH: Terra sigillata magángyüjtemény Sárvár és környékéről (Terra Sigillaten aus einer Privatsammlung).

ComArchHung 2001, 90.
${ }^{200}$ GableR-PALÁGYi 1989, Nr. 8.

${ }^{201}$ MEES 2002, 343.

${ }^{202}$ D. GABLER: Terra Sigillaten in der Zivilstadt von Aquincum. Wien - in press

${ }^{203}$ R. Christlein-W. CZysz-J. Garbsch-H.-J. KellnerP. SCHRÖTER: Die Ausgrabungen 1969-1974 in Pons Aeni. BVbl 41 (1976) 78.

${ }^{204}$ GABLER-KELLNER 1993, 96.

${ }^{205}$ F. REUTTI: Tonverarbeitende Industrie im römischen Reich. Vorbericht für die Grabungen der Jahre 1978-1981. Germania 31 (1983) 58-60.

${ }^{206}$ K. KortüM-A. W. MeEs: Die Datierung der Rheinzaberner Relieftöpfer. In: Form and Fabric. Studies in Rome's material past in honorem of B. R. Hartley. Ed.: J. Bird. Oxford 1998, 162. 
around 233; however, this is debated by M. Struck. ${ }^{207}$ Data from the deposits from Vindobona and Carnuntum also provide evidence that production at Westerndorf finished in the third quarter of the $3^{\text {rd }}$ century. ${ }^{208}$

Among plain ware, No. 8 deserves further attention. The Drag. 39 (= LuD 5, Oa) form, a lanx, was certainly made at Rheinzabern, not only because it is also present in material at that production centre, but also because its stamped examples (Iustus, ${ }^{209}$ Iuvenis, Crassiacus, Magio etc.) can be related to this centre. The form itself is an early one: it is to be found in assemblages in the period dating from Trajan - middle of the $2^{\text {nd }}$ century at Pforzheim, it was found in a filling of well No. 9 which can be dated to the second half of the $2^{\text {nd }}$ - first half of the $3^{\text {rd }}$ century. Since the form is missing - with the exception of the Regensburg cemetery ${ }^{210}$ - from the material of the Niederbieber horizon, its most probable date is the second half of the $2^{\text {nd }}$ century.

The destruction layer of the $6^{\text {th }}$, and the levelled layer of the $7^{\text {th }}$ phase of Köln-Alteburg more or less supports this sequence. ${ }^{211}$ A somewhat earlier dating can also be considered on the basis of a Juvenis stamp, which emerged at Lauriacum. ${ }^{212}$ The form is present at Veldidena and Wallsee. ${ }^{213}$ Baláca. ${ }^{214}$

Multiple examples of the Drag. 39 form lanx are also present in the material from the nearby villa farm of

Based on the above described samian, the Roman settlement at Papkeszi was inhabited in the Flavian Age, or at the latest, at the very end of the $1^{\text {st }}$ century. Although its inhabitants might have hidden a deposit of terra sigillata as a significant treasure, the Marcomannic-Sarmatian wars did not cause any considerable interruption in the life of the settlement. The development and persistence of the settlement can be traced until the middle of the $3^{\text {rd }}$ century or even beyond.

\section{Fibulae}

1. Kräftig profilierte fibula with a single knob (Fig. 13.1)

Almgren 68 form, Kovrig T. V.41-44; Patek T. IV.9-10; Jobst IV B; Rieckhoff 4.5.2 variant; Bojović 9.2 variant; Berecz II.2 Aa variant; Heymans 4.3.8.2 variant; Mazur 2.9.2 variant; Ortisi 7 c variant; Cociş 8a1b1 and 8a1b2 variant; Gencseva 9 b variant; Merczi 2012, 7. variant, 3. picture 1. (Fig. 13.1)

Unilateral, flaring near the head, the spiral consisted of 8 spins originally, of which 4 are visible. Its pin is broken, the head is hardly folded back, the bow knob is divided into sections, oval - widening mostly to the upper part of the bow. The slightly curved foot is divided into sections, ending in a biconical, pointed knob mounting above the level of the foot. The pin holder is of trapezoidal shape, incomplete, but presumably having no intersection. The pin holder is broken.

L: $5.5 \mathrm{cms}, \mathrm{w}: 2.2 \mathrm{cms}$

Claudian-Flavian

The Kräftig profilierte fibula with a single knob was the most popular and most variable Roman brooch type along the Middle Danubian territories and more locally, within Pannonia. Types corresponding to Almgren 67-73, without a plate, were spread across great areas in the Danubian provinces. Their origins can be traced to the

${ }^{207}$ M. STRUCK: Römische Grabfunde und Siedlungen im Isartal bei Ergolding, Ldkr. Landshut. MhBV A. Reihe 71. Kallmünz/Opf 1996, 52.

${ }^{208}$ S. RADBAUER: The Roman Terra sigillata production of Westerndorf (South Bavaria, Germany). History, location and technology. In: Seeing Red. New economic and social perspectivies on GalloRoman terra sigillata. Ed.: M. Fulford, E. Durham. BICS suppl. 102. London 2013, 162.

${ }^{209}$ D. PlancK: Arae Flaviae. I.: Neue Untersuchungen zur Geschichte des römischen Rottweil. Forschungen und Berichte zur Vor- und Frühgeschichte in Baden-Württemberg 6. Stuttgart 1975, Taf. 90,7.

${ }^{210}$ S. vON SCHNURBEIN: Das römische Gräberfeld von Regensburg. MhBV A. Reihe 31. Kallmünz/Opf 1977, Taf. 12,1.
${ }^{211}$ A. DÜERKOP-P. EschBAUMER: Die Terra Sigillata im römischen Flottenlager an der Alteburg in Köln. Das Fundmaterial der Ausgrabung 1998. Kölner Studien zur Archäologie der römischen Provinzen 9. Rahden/Westf. 2007, 116.

${ }^{212}$ E. M. Ruprechtsberger: Terra Sigillata aus dem Ennser Museum. II.: Kerbschnitt- und Barbotinesigillata, unverzierte Sigillata, Töpferstempel und Ritzinschriften. Linz 1980, Taf. 39,3.

${ }^{213}$ Ibidem.

${ }^{214}$ Gabler-PalÁGYi 1989, 121; D. Gabler: A balácai terra sigillaták (Terra Sigillaten) II. BalácaiKözl 2 (1992) 316; D. GABLER: A balácai terra sigillaták (Die Terra sigillata von Baláca). 3. BalácaiKözl 6 (2001) 125. 
Eastern regions of the Alps. ${ }^{215}$ Our type, Almgren 68, besides Noricum and Pannonia, was present also in the barbaricum, and was spread as far as the Baltic and Southern Scandinavia, and in a smaller scale, along the lower sections of the Danube. Its precedessor was already present at Magdalensberg, ${ }^{216}$ but it is also present in assemblages dated up to the late Flavian age or the turn of the $1^{\text {st }}-2^{\text {nd }}$ century, too. ${ }^{217}$

\section{Knee fibula}

Almgren 246-248; Berecz III. type; Berecz 1991, 7. type 7 Ab variant; Bojović 20/3 variant; Böhme 19-21; Cociş 19. type; Gencseva 16-17. type; Gugl 13. type; Jobst 12-13. type; Kovrig X. group; Merczi 13. type; Schleiermacher V. type; Ortisi 19. type (Fig. 13.2)

The semicircular head is connected to a triangular cross-sectioned bow, the upper sides of the bow are curved, and it widens at the bend and the foot, while it bends towards the inside at the middle. The spring flares near the head and consists of 8 spins. There is a collar at the borderline of the bow and the head. The rim of the head was probably decorated. The base of the bow is incomplete. The pin holder is tall and narrow.

L.: $3.2 \mathrm{cms}$, W.: $1.8 \mathrm{cms}$

Antonine-Septimius Severus

This variant is present in the Northern part of Pannonia and along the Amber Road, but it can also be found in Moesia and Dacia. ${ }^{218} \mathrm{Ch}$. Gugl dated it to the Antonine - early Severan Age. ${ }^{219}$ Fibulae belonging to this type were probably on the market still in the first decades of the $3^{\text {rd }}$ century.

\section{ACKNOWLEDGEMENTS}

Hereby we express our gratitude to István Horváth $(† 2016)$ (Berhida), for turning in his rich collection, consisting of finds from archaeological sites from the surroundings of Papkeszi and Berhida, to the Hungarian National Museum. It is a particularly pleasant duty to record our warmest gratitude to Dr. Margaret Ward, who read substantial sections of the draft manuscript and made numerous suggestions for improvements. She has made many alterations in the text and brought the material into a publishable form. We would like to thank Magda Eber, who has produced many of the drawings.

Many thanks to the Field Survey Team of the Hungarian National Museum and Zoltán Kramli, Miklós Molnár, Tamás Szabadváry as well for their help. The vessels of the terra sigillata set were restored by Gábor Hutai and Márta Posta (Hungarian National Museum). We express our special thanks for their work.

\section{REFERENCES}

ALFÖLDY 1969

ALMGREN 1923

BARKÓCZI-BóNIS 1954

BAKKER-GALSTERER-KRÖLL 1975
$=$ G. ALFöLDY: Die Personennamen in der römischen Provinz Dalmatia. Beiträge zur Namenforschung N.F. Bh 4. Heidelberg 1969.

$=$ O. ALMGREN: Studien über nordeuropäische Fibelformen der ersten nachchristlichen Jahrhunderte mit Berücksichtigung der provinzialrömischen und südrussischen Formen. Mannus-Bibliothek 23. Leipzig 1923.

= L. BARKóCZI-É. BóNIS: Das frührömische Lager und und die Wohnsiedlung von Adony (Vetus Salina). ActaArchHung 4 (1954) 129-199.

= L. BAKKER-B. GALSTERER-KRÖLL: Graffiti auf römischer Keramik im Rheinischen Landesmuseum. Epigraphische Studien 10. Bonn 1975.
${ }^{215}$ M. MERCZI: Támlap nélküli egygombos, erősprofilú fibulák Északkelet-Pannoniából (Kräftig profilierte Fibeln ohne Stützplatte aus NO-Pannonien). Kuny Domokos Múzeum Közleményei 20 (2014) 22.

${ }^{216}$ H. Sedlmayer: Die Fibeln von Magdalensberg. Funde der Grabungsjahre 1948-2002 und Altfunde des 19. Jahrhunderts. Kärntner Museumsschriften 79. Archäologische Forschungen zu den Grabungen auf dem Magdalensberg 16. Klagenfurt 2009, 33
${ }^{217}$ CH. GuGL: Le "kräftig profilierten Fibeln" del Friuli. Uno sguadro di insieme. In: Fibule antiche del Friuli. A cura di M. Buora, St. Seidel. Cataloghi e monografie archeologiche del Civici Musei di Udine 9. Udine 2008, 34; M. MerCzI: A Budaörs-Kamaraerdei dülöben feltárt temető fibulái [Brooches of the Roman cemetery at Budaörs-Kamaraerdei dülő]. In: A budaörsi római vicus temetője. Ed.

K. Ottományi. Régészeti tanulmányok. Budapest 2016, 436.

${ }^{218}$ MERCZI 2012, 495-496.

${ }^{219}$ Gugl 1995, 35; SchMid 2010, 90. 
BARKÓCZI 1964

BARTA 2006

BARTA 2015

BÁNKI 1987

BERECZ 1990

BERECZ 1991

BET 1988

Bet-Delage 1991

BILKEI 1985

BÍRÓ 2007

BÍRÓ 2017

BJELAJAC 1990

BoJOVIĆ

BÖHME

CGP

CoCIȘ 2004

CSIR U VIII

Curle 1911

CZYsZ 1982

CSIRKE-GABLER-PALÁGYi 2006

DICKINSON 2001

DONAT 1999

DÜERKOP-ESCHBAUMER 2007

ETTLINER 1969-1970

FABER 1994

FEHÉR 2013

FISCHER 1994

FISCHER 2012a
= L. BARKóczi: The population of Pannonia from Marcus Aurelius to Diocletian. ActaArchHung 16 (1964) 257-356.

= A. BARTA: Római kori feliratos edénytöredékek Zalalövőről (Römerzeitliche Gefässfragmente mit Inschriften von Zalalövő). ComArchHung 2006, 123-148.

$=$ A. BARTA: Interpretation of the graffiti. In: The early and late Roman rural cemetery at Nemesböd (Vas County, Hungary). Ed. by G. Ilon. Roman Archaeology 5. Oxford 2015, 67-68.

= Zs. BÁNKI: Forschungen in Gorsium in den Jahren 1983-84. Alba Regia 23 (1987) 179-240.

= K. BERECZ: Römerzeitliche Fibeln aus Zalalövő. RFiZ. ActaArchHung 42 (1990) 77-96.

= K. BERECZ Z: Római kori fibulák Zala megyéből.1. (Roman brooches from Zala County) ZalaiMúz 3 (1991) 163-183.

= PH. Bet: Groupes d'ateliers et potiers de Lezoux (Puy-d.Dôme) durant la période gallo-romaine. In: SFECAG, Actes du Congrès d'Orange 1988, 221-241.

$=$ Ph. Bet-R. Delage: Introduction à l'étude des marques sur sigillée moulée de Lezoux. In: SFECAG, Actes du Congrès de la Cognac 1991, 193-227.

= I. BILKEI: Római edényfeliratok a nagykanizsai Thury György Múzeumban (Inschriften auf römischen Gefässe in dem Thury György Museum in Nagykanizsa). In: Közlemények Zala megye közgyüjteményeinek kutatásaiból 1984-1985. Hrsg.: Alajos Degré, Imre Halász. ZalaiGyüjt 21. Zalaegerszeg 1985, 5-21.

= Sz. Bíró: A Sokoró vidéke a római korban - The Sokoró Region in the Roman Period. In: FiRKák I. Fiatal Római Koros Kutatók I. Konferenciakötetet. Xantus János Múzeum, Győr 2006. március 8-10. Hrsg. Sz. Bíró. Győr 2007, 17-53.

= Sz. Bíró: Die zivilen Vici in Pannonien. RGZM Monographien 131. Mainz 2017.

= L. BJELAJAC: Terra sigillata in Upper Moesia; import and Viminacium-Margum workshop. Belgrade 1990.

= D. Bojović: Rimske fibule Singidunuma (Roman brooches from Singidunum). Zbirke i legati/Muzej grada Beograda, Katalog 12. Beograd 1983.

= A. BöHME: Die Fibeln der Kastelle Saalburg und Zugmantel. SaalburgJb 29 (1972) 5-112.

= J. A. StANFiEl-G. Simpson: Les potiers de la Gaule Centrale. Revue archéologique Sites, hors-série 37. Gonfaron 1990.

= S. Cociș: Fibulele din Dacia Romană - The Brooches from Roman Dacia. Bibliotheca Ephemeris Napocensis 3. Cluj 2004.

= C. ERTEl-S. PAlÁgYi-F. S. Redō: Corpus signorum imperii Roman - Corpus der Skulpturen der römischen Welt. Ungarn, 8.: Die Skulpturen des Stadtgebietes von Salla und Mogetiana sowie des Balaton-(Plattensee-) Oberlandes in den Komitaten Zala und Veszprém. Budapest 1999.

= J. Curle: A Roman Frontier Post and its People. The fort of Newstead in the parish of Melrose. Glasgow 1911.

= W. CzYsz: Der Sigillata-Geschirrfund von Cambodunum-Kempten. Technologie und Handelskunde mittelkaiserzeitlicher Keramik. BRGK 63 (1982) 281-348.

= O. Csirke-D. Gabler-S. K. PALÁGYi: Terra sigillata edények a veszprémi Laczkó Dezső Múzeum gyűjteményéből (Terra Sigillata. Gefässe des Museums „Laczkó Dezső” von Veszprém). Veszprém 2006.

= B. M. Dickinson: The potter's stamps. In: A. S.Anderson-J. S. Wacher-A. P. Fitzpatrick: RomanoBritish "Small Town" at Wanborough, Wiltshire: Excavations 1966-1976. Britannia monograph series 19. London 2001.

= P. DonAt: Zur Herkunft der Terra Sigillata von der Ausgrabung Michaelerplatz. Fundort Wien 5 (1999) 210-215.

= A. DÜERKOP-P. EsCHBAUMER: Die Terra Sigillata im römischen Flottenlager an der Alteburg in Köln. Das Fundmaterial der Ausgrabung 1998. Kölner Studien zur Archäologie der römischen Provinzen 9. Rahden/Westf. 2007.

= E. ETTLINGER: Frühkaiserzeitliche Sigillaten aus Baden-Aquae Helveticae. Gesellschaft Pro Vindonissa 1969-1970, 82-105.

= A. FABER: Das römische Auxiliarkastell und der Vicus von Regensburg-Kumpfmühl. MBV 49. München 1994.

= B. FeHÉR: Paleográfiai adatok az aquincumi kézírásos emlékeken (Paleographical data on graffiti from Aquincum). Studia epigraphica Pannonica 5. Buddapest 2013, 22-58.

= T. FISCHER: Archäologische Zeugnisse der Markomannenkriege (166-180 n.Chr.) in Raetien und Obergermanien. In: Die Markomannenkriege: Ursachen und Wirkungen. 6. Internationales Symposium „Grundprobleme der frühgeschichtlichen Entwicklung im nördlichen Mitteldonaugebiet“. Hrsg.: H. Friesinger, Tejral, A. Stuppner. Brno 1994, 341-354.

$=$ TH. FISCHER: Archaeological evidence of the Marcomannic wars of Marcus Aurelius (AD 166-180). In: A Companion to Marcus Aurelius. Ed.: M. van Ackeren. Chichester 2012, 29-44. 
FISCHER 2012b

FÜLEP 1958

GABLER 1964

GABLER 1989

GABLER 1994

GABLER 1997

GABLER-KELLNER

GABLER-KocZTUR 1976

GABLER-MÁrTON 2009

GABLER-PALÁGYI 1989

GENČEva

GuGL

HARTLEY 1972

HARTLEY 2000

HEYMANS

HINKER 2014

HoRVÁTH 1979

HoRVÁTH-TOKAI-TóTH 2012

IIL 1991

JACOBS 1912

JOBST 1975

JUHÁSZ 1935

JuHÁSZ 1936

KARNITSCH 1959

KNORR 1919

KoCZTUR 1991

KovÁCS-FeHÉR 2001

KovÁcs 2009

KovRIG

KuZMOVÁ 2016

KUZSINSZKY 1920

LŐRINCZ 1999
$=$ TH. FISCHER: Die Armee der Caesaren. Archäologie und Geschichte. Regensburg 2012

= F. FÜLEP: Das frühkaiserzeitliche Gräberfeld von Vasas. ActaArchHung 9 (1958) 371-406.

= D. GABLER: Az importált terra sigillaták forgalma Pannoniában (Angaben zur Verbreitung der $\mathrm{Si}$ gillaten in Pannonien). ArchÉrt 91 (1964) 94-110.

= D. GABLER: Die Sigillaten von Salla (Zalalövő). Grabungen 1982-1983. ActaArchHung 41 (1989) 435-475.

= D. GABLER: Über die Aussagekraft der Terra Sigillata-Funde bezüglich der Zerstörungen in den Provinzen. In: Die Markomannenkriege - Ursachen und Wirkungen. 6. Internationales Symposium „Grundprobleme der frühgeschichtlichen Entwicklung im nördlichen Mitteldonaugebiet“. Hrsg.: H. Friesinger, J. Tejral, A. Stuppner. Brno 1994, 355-364

= D. GABLER: Die römische Straßenstation von Sárvár und ihre Vorgängerbauten aus dem 1. Jahrhundert n.Chr. CarnuntumJb 1997, 23-82.

= D. GABLER-H.-J. KelLNER: Die Bildstempel von Westerndorf. II: Helenius und Onniorix. BVbl 58 (1993) 185-270.

= D. GABLER-É. KocztuR: Terra Sigillata Depotfund aus Gorsium. Alba Regia 15 (1976) 65-81.

= D. GABLER-A. MÁRTON: La circulation des sigillées en Pannonie d'après les estampilles sur sigillées lisses de Gaule, de Germanie et de la région danubienne. RAE 58 (2009) 205-324.

= D. GABLER-S. PALÁGYI: A balácai terra sigillaták (Terra Sigillaten aus Baláca). 1. BalácaiKözl 1 (1989) 109-134

$=\mathrm{J}$. GenČEva: Rimskite fibuli ot Bulgarije - Les fibules romaines de Bulgarie de la fin du $1^{\mathrm{er}} \mathrm{s}$. av. J.C-à la fin du VI ${ }^{\mathrm{e}}$ s. ap. J.C. Veliko Tarnovo 2004.

$=$ CH. Gugl: Die römischen Fibeln aus Virunum. Klagenfurt 1995.

= B. R. HARTLEY: The Roman occupation of Scotland: the evidence of Samian ware. Britannia 3 (1972) 4-15.

= B. R. Hartley: The Samian. In: E. Evans: The Caerleon Canabae. Excavations in the Civil Settlement 1984-1990. Britannia monograph series 16. London 2000.

= H. Heymans: Die Fibeln aus dem römerzeitlichen Vicus von Kalsdorf bei Graz. FÖ 36 (1997) $325-374$.

$=$ CH. HinKer: Ein Brandhorizont aus der Zeit der Markomannenkriege im südostnorischen Munizipium Flavia Solva. Mit Beiträgen von G. Christandl, U. Schachinger. Zentraleuropäische Archäologie 4. Wien 2014

= L. HORVÁTH: A magyarszerdahelyi kelta és római temető (Die keltische und römische Gräberfeld in Magyarszerdahely). ZalaiGyüjt 14. Zalaegerszeg 1979

= L. HoRvÁTH-Z. M. ToKAI-G. TóTH: Kora császárkori temető Alsópáhokon (Zala megye) - Excavation report on an Eraly Imperial period cemetery at Alsópáhok, Zala County. In: Jelentés/Kulturális Örökségvédelmi Szakszolgálat 2009. Budapest 2012, 163-222.

$=$ Instrumenta inscripta Latina. das römische Leben im Spiegel der Kleininschriften. Ausstellungskatalog. Hrsg.: M. Hainzmann, Zs. Visy. Pécs 1991.

= J. JACOBS: Sigillatafunde aus einem römischen Keller zu Bregenz. JfA 6 (1912) 172-184.

= W. JoBst: Die römischen Fibeln aus Lauriacum. FiL 10. Linz 1975.

= Gy. JuHÁsz: Die Sigillaten von Brigetio. DissPann II/3. Budapest 1935.

= Gy. JuHÁsz: A lezouxi terra sigillata gyárak aquicumi lerakata (Die aquincumer Niederlage der Terra Sigillata Fabriken von Lezoux). ArchÉrt 49 (1936) 33-48.

= P. KARNITSCH: Die Reliefsigillata von Ovilava, Wels Oberösterreich. Schriftenreihe des Instituts für Landeskunde von Oberösterreich 12. Linz 1959.

$=$ R. KNORR: Töpfer und Fabriken verzierter Terra-Sigillata des ersten Jahrhunderts. Stuttgart 1919.

= É. KoczTUR: Kora császárkori temető Solymáron (Frühkaiserzeitliches Gräberfeld in Solymár). StComit 21 (1991) 171-334.

= P. KovÁCS-B. FeHÉR: Feliratos tégla- és edénytöredékek a balácai római kori villából I. Vicus Augusti Pannoniában. BalácaiKözl 6 (2011) 159-181.

= P. KovÁcs: Marcus Aurelius' Rain Miracle and the Marcomannic Wars. Mnemosyne suppl. 308. Leiden 2009.

= I. KKVRIG: A császárkori fibulák föformái Pannoniában-Die Haupttypen der kaiserzeitlichen Fibeltypen in Pannonien. DissPann II/4. Budapest 1937.

$=$ K. KuZMová: Evidence of the plain ware of Paullus from Lezoux in Pannonia. Acta RCRF 44 (2016) 601-607.

= B. KuZSINSZKY: A Balaton környékének archaeologiája (The Archaeology of the Surroundings of Lake Balaton). Budapest 1920.

= B. LöRINCZ: Onomasticon Provinciarum Europae Latinarum. II: Cabalicius-Ixus: ex materia ab András Mócsy, Reinhardo Feldmann, Elisabetha Marton et Mária Szilágyi collecta. Wien 1999. 
LUD V

LUD VI

MeEs 1995

Mees 2002

MERCZI 2012

Mikl CuRK 1969

MóCsy 1959

MrÁv 2014

MRT 2

Names I

Names 2

Names 3

Names 7

Names 8

$\mathrm{O}$.

ORTISI 2002

OSWALD-PRYCE

OTTOMÁNYI-GABLER 1985

PATEK 1942

PFERDEHIRT 1976

POLAK 2000

Pudding-pan Rock

RIECKHOFF 1975

$\mathrm{Ri}-\mathrm{Fi}$

Rogers 1999

SCHLEIERMACHER 1993

SCHMID 2010

SCHOLZ 2015
= W. LudowicI: Katalog V. Stempel Namen und Bilder römischer Töpfer aus meinen Ausgrabungen in Rheinzabern, 1901-1914. Darmstadt 1927.

= W. Ludovici: Katalog. Rheinzabern VI. Textband. Bearb. von H. Ricken und Ch. Fischer. Bonn 1963.

= A. W. MeEs: Modelsignierte Dekorationen auf südgallischer Terra Sigillata. Forschungen und Berichte zur Vor- und Frühgeschichte in Baden-Württemberg 54. Stuttgart 1995.

= A. W. MeEs: Organisationsformen römische Töpfer-Manufakturen am Beispiel von Arezzo und Rheinzabern. Römisch-Germanisches Zentralmuseum Monographien 52. Mainz 2002.

= M. MercZI: A Budaörs-Kamaraerdei dülőben feltárt római vicus fibulái (Die Fibeln des römischen vicus in Budaörs-Kamaraerdei dülő). In: K. Ottományi: Római vicus Budaörsön. Budapest 2012, $455-528$.

= I. MIKL CURK: Terra sigillata in sorodne vršte keramike iz Poetovija (Terra Sigillata und ähnliche Keramikgattungen aus Poetovio). Dissertationes 9. Ljubljana 1969.

= A. MócsY: Die Bevölkerung von Pannonien bis zu den Markomannenkriegen. Budapest 1959.

= Zs. MrÁv: Római feliratok és faragott kőemlékek Budaörsről. In: K. Ottományi-Zs. Mráv-I. Filipszky-E. Mester: Antik gyökereink. Budaörs múltja a régészeti leletek fényében. Budaörs 2014, 79-113.

= I. ÉRI-M. KELEMEN-P. NÉMETH-I. TORMA: Veszprém megye régészeti topográfiája. 2.: A veszprémi járás. Magyarország régészeti topográfiája (Archaeological sites of Hungary). 2. Budapest 1969.

= B. R. Hartley-B. M. Dickinson: Names on Terra Sigillata: An Index of makers' stemps and signatures on Gallo-Roman terra sigillata (Samian ware). I.: A to Axo. BICS suppl. 102/1. London 2008.

= B. R. Hartley-B. M. Dickinson: Names on Terra Sigillata: An Index of makers' stamps and signatures on Gallo-Roman terra sigillata (Samian ware). 2.: B to Cerotcus. BICS suppl. 102/2. London 2008.

= B.R. HARTLEY-B. M. Dickinson: Names on Terra Sigillata: An Index of makers stamps and signatures on Gallo-Roman terra sigillata (Samian ware). 3.: Cerianus to Exsobano. BICS suppl. 102/3. London 2008

= B.R. Hartley-B. M. Dickinson: Names on Terra Sigillata. An Index of makers' stamps and signatures on Gallo-Roman terra sigillata (Samian ware). 7.: P to RXEAD. BICS suppl. 102/7. London 2011.

= B.R. HARTLEY-B. M. Dickinson: Names on Terra Sigillata. An Index of makers'stamps and signatures on Gallo-Roman terra sigillata (Samian ware). 8.: T to Ximus. BICS suppl. 102/8. London 2012.

= F. OswaLD: Index of Figure Types on Terra sigillata. Liverpool 1936-1937.

= S. ORTISI: Die früh- und mittelkaiserzeitlichen Fibeln. In: S. Ortisi-P. M. Pröttel: Römische Kleinfunde aus Burghöfe. 2. Frühgeschichtliche und provinzialrömische Archäologie 6. Rahden/Westf. 2002, 9-82

= F. Oswald-T. D. PrycE: An Introduction to the Study of Terra Sigillata Treated from a Chronological Standpoint. London 1920. repr. 1966.

= K. Ottományi-D. Gabler: Római telepek Herceghalom és Páty határában. A pátyi terra sigillata (Römische Siedlungen in der Gemarkung von Herceghalom und Páty). StComit 17 (1985) 185-241.

$=$ E. PATEK: A pannóniai fibulatípusok elterjedése és eredete - Verbreitung und Herkunft der römische Fibeltypen in Pannonien. DissPann II/19. Budapest 1942.

= B. PferdeHIRT: Die Keramik des Kastells Holzhausen. Limesforschungen 16. Berlin 1976.

= M. POLAK: South Gaulish Terra Sigillata with Potters' Stamps from Vechten. Acta RCRF suppl. 9. Nijmegen 2000 .

$=$ R. A. Smith: The Diving Operations on Pudding-pan Rock, Herne Bay, Kent and the Gallo-Roman Red Ware Recently Recovered from the Rock. Proceeding of the Society of Antiquities. London 1909.

= S. RIECKHOFF: Münzen und Fibeln aus dem Vicus des Kastells Hüfingen (Schwarzwald-Baar Kreis). SaalburgJb 32 (1975) 5-104.

= H. RICKEN-CH. FISCHER: Die Bilderschüsseln der römischen Töpfer von Rheinzabern. Bonn 1963.

= G. B. Rogers: Poteries sigillées de la Gaule centrale. II.: Les potiers. 2. Revue archéologique Sites: Hors série 40. Lezoux 1999.

= M. SchleIERMACHER: Die römischen Fibeln von Kempten-Cambodunum. MhBV A. Reihe: Fundinventare und Ausgrabungsbefunde 63. Cambodunumforschungen 5. Kallmünz/Opf. 1993, 11-44.

= S. SchMid: Die römischen Fibeln aus Wien. Monographien der Stadtarchäologie 6. Wien 2010.

= M. Scholz: Tumbe Bauern? Zur Schriftlichkeit in ländlichen Siedlungen in den germanischen Provinzen und Raetien. In: Lesen und Schreiben in den römischen Provinzen. Schriftiche 
SIMON 2014

SzABÓ et al. 2014

TILHARD 2004

WALKE 1965

WALTERS 1908

WEBER-HidEN 1996
Kommunikation im Alltagsleben. Akten des 2. Internationalen Kolloquiums von DUCTUS. RGZM Mainz, 15-17. Juni 2011. Hrsg.: M. Scholz, M. Horster. RGZM-Tagungen 26. Mainz 2015, 67-90. = B. SimON: Nemesbőd-Irtásdülő: Egy korarómai birtok Savaria territóriumán? (Nemesbőd-Irtásdülő. An eraly Roman estate on the territory of Savaria?). In: FiRKák III. Fiatal Római koros Kutatók III. Konferenciakötete. Ed.: P. Balázs. Szombathely 2014, 327-342.

= M. Szabó-A. Kiss-R. Molnár-B. Nagy-R. Neményi-A. Szabó-P. N. Takács-I. Talabér: Előzetes jelentés a Cserdi község (Baranya megye) melletti római villagazdaság 2012. évi próbafeltárásáról és terepi kutatásáról (Roman villa at Cserdi (Baranya county) - a preliminary report on archaeological investigations conducted in 2012). In: FiRKák III. Fiatal Római koros Kutatók III. Konferenciakötete. Ed.: P. Balázs. Szombathely 2014, 255-304.

= J.-L. TILHARD: Les céramiques sigillées du Haut Empire d'après les estampilles et les décors moulé. Marseille 2004.

= N. WaLKE: Das römische Donaukastell Straubing-Sorviodurum. Berlin 1965.

$=$ H. B. WALTERs: Catalogue of the Roman Pottery in the Departments of Antiquities British Museum. London 1908.

= I. WeBER-Hiden: Die reliefverzierte Terra Sigillaten in Vindobona. I.: Legionslager und Canabae. WAS 1. Wien 1996. 